\title{
Early diagenetic overprint in Caribbean sediment cores and its effect on the geochemical composition of planktonic foraminifera
}

\author{
M. Regenberg ${ }^{1, *}$, D. Nürnberg ${ }^{1}$, J. Schönfeld ${ }^{1}$, and G.-J. Reichart ${ }^{2}$ \\ ${ }^{1}$ Leibniz Institute of Marine Sciences IFM-GEOMAR, Kiel, Germany \\ ${ }^{2}$ Faculty of Earth Sciences, Utrecht University, The Netherlands \\ *now at: Institute of Geosciences, Christian-Albrechts-University, Kiel, Germany
}

Received: 7 June 2007 - Published in Biogeosciences Discuss.: 4 July 2007

Revised: 23 October 2007 - Accepted: 29 October 2007 - Published: 12 November 2007

\begin{abstract}
Early diagenetic features are noticed in the vicinity of carbonate platforms. Planktonic foraminifera of two tropical Atlantic deep-sea sediment cores show the strict relation between micro-scale euhydral crystallites of inorganic precipitates, higher oxygen isotope values and $\mathrm{Mg} / \mathrm{Ca}$ ratios, and lower $\mathrm{Sr} / \mathrm{Ca}$ ratios than expected for their pelagic environment in the time interval of $\sim 100000-550000$ calendar years before present. Laser ablation $\mathrm{Mg} / \mathrm{Ca}(\mathrm{Sr} / \mathrm{Ca})$ of crystallite-bearing foraminiferal chamber walls revealed 46 times elevated (2-3 times depleted) ratios, when ablating the diagenetic overgrowth. Crystalline overgrowth in proportion of $10-20 \%$ are estimated to cause the observed geochemical alteration. The extent of foraminiferal $\mathrm{Mg} / \mathrm{Ca}$ alteration, moreover, seems to be controlled by the composition of the bulk sediment, especially the content of highmagnesium calcite. Anomalous ratios of $>6 \mathrm{mmol} / \mathrm{mol}$ only occur, when high-magnesium calcite has dissolved within the sediment. The older parts (back to $\sim 800 \mathrm{kyrs}$ ) of the records are characterized by similar trends of $\mathrm{Mg} / \mathrm{Ca}$ and $\mathrm{Sr} / \mathrm{Ca}$. We discuss possible scenarios to accommodate the obtained geochemical information.
\end{abstract}

\section{Introduction}

A persistent problem in many paleoceanographic studies is the potential of diagenetic processes to compromise the fidelity of geochemical proxies in deep-sea carbonates and microfossils, such as foraminifera. Principally, two processes of deep-sea carbonate diagenesis can be distinguished from each other: Firstly, the geochemical composition may be biased by dissolution processes on the sediment's carbonate mineralogy (e.g., Droxler, 1984; Sabine and Mackenzie, 1995; Haddad and Droxler, 1996; Malone et al., 2001;

Correspondence to: M. Regenberg

(regenberg@gpi.uni-kiel.de)
Frank and Bernet, 2000; Jansen et al., 2002), and on the foraminiferal isotope and element content (e.g., Lorens et al., 1977; Lohmann, 1995; Rosenthal et al., 1997; Dekens et al., 2002; Regenberg et al., 2006a). Secondly, the geochemical composition may be altered by reprecipitation of calcite from sediment pore fluid (e.g., Baker et al., 1982; Norris and Wilson, 1998; Hover et al., 2001; Rudnicki et al., 2001) and manganese/iron (hydr)oxide coatings (e.g., Boyle, 1983; Reichart et al., 2003; Pena et al., 2005). Dissolution and/or inorganic reprecipitation is determined by the saturation state of seawater or pore fluid with respect to the solid phase (e.g., Morse, 2003; Funk et al., 2003; Regenberg et al., 2006a). Inorganic (or diagenetic) calcite in terms of overgrowth may mask the primary oceanographic signal of planktonic foraminiferal tests. Both, inorganic calcite overgrowth and dissolution of foraminiferal tests during shallow burial tend to bias the oxygen isotope composition $\left(\delta^{18} \mathrm{O}\right)$ to more positive values (Killingley, 1983; Mulitza et al., 2004).

A paramount aim of geochemical studies focussing on diagenetic issues is quantification of the alteration. One strategy for quantifying the extent of diagenesis is the application of numerical models to assess pore-fluid and precipitate isotope compositions (e.g., Killingley, 1983; Richter and DePaolo, 1987; Schrag et al., 1992; Schrag, 1999; Rudnicki et al., 2001). Basically, these studies address deep-buried sediments from depths of $>300 \mathrm{~m}$. Another approach for the quantification of diagenetic alteration deals with the Element/Ca ratios and their alignment to measured pore-fluid composition by application of partition coefficients (e.g., Tripati et al., 2003; Sexton et al., 2006).

Here, we found unexpected diagenetic overprint in shallow-buried sediments in tropical Atlantic and Caribbean deep-sea cores from different water depths ( 1700-2700 m; Fig. 1) marginally described before (Müller, 1999). We applied oxygen isotope and Element/Ca analysis on bulk planktonic foraminiferal tests revealing anomalous ratios compared to established data sets reflecting past environmental

Published by Copernicus Publications on behalf of the European Geosciences Union. 


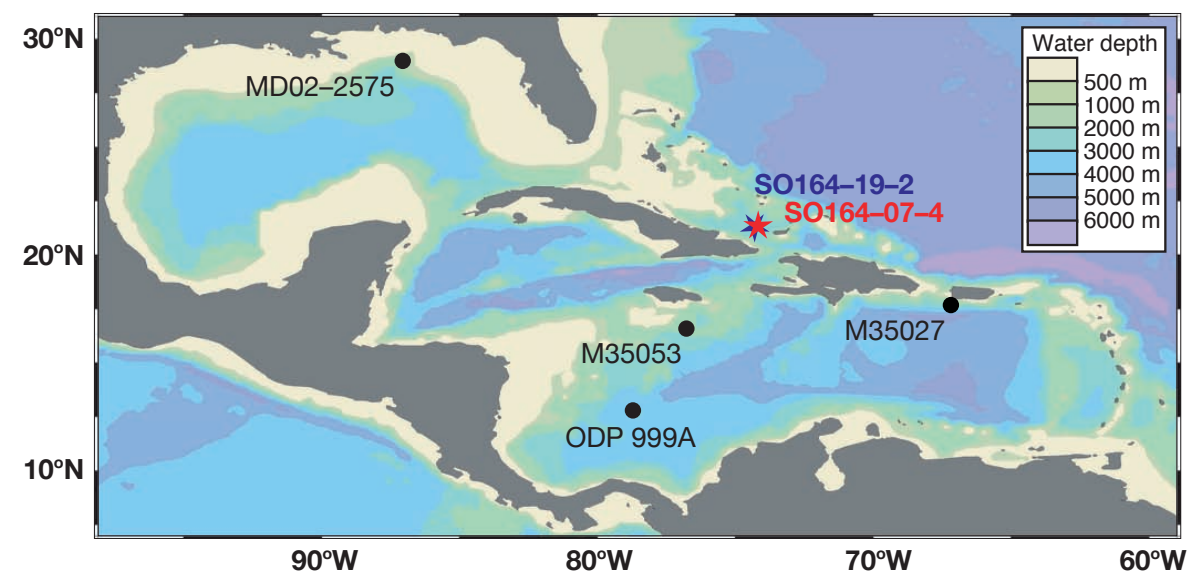

Fig. 1. Bathymetric chart of the Caribbean and the Gulf of Mexico generated with Ocean Data View (Schlitzer, 2002): Stars indicate the site locations of the examined sediment cores SO164-07-4 and SO164-19-2. For comparison, data of sites MD02-2575 (847 m water depth), M35027 (1814 m), M35053 (1698 m), and ODP 999A (2827 m) are shown in this study.

conditions. Since information on the bulk foraminiferal geochemical composition altered by diagenesis combines the actual biogenic calcite signal and the composition of the inorganic precipitate, we additionally performed laser ablation inductively coupled plasma mass spectrometry capable to generate high resolution Element/Ca-ratio profiles of foraminiferal tests (Eggins et al., 2003; Hathorne et al., 2003; Reichart et al., 2003). This technique allows to determine end-member compositions of the diagenetic precipitates. Associated carbonate mineralogy of the bulk sediment affords the possibility to characterize the processes involved in sediment alteration.

\section{Materials and methods}

Piston cores SO164-07-4 and SO164-19-2 were recovered during R/V SONNE cruise 164 (Nürnberg et al., 2003) from Windward Passage $\left(21^{\circ} 19^{\prime} 27.6^{\prime \prime} \mathrm{N}, 74^{\circ} 08^{\prime} 46.2^{\prime \prime} \mathrm{W}\right.$ at $2722 \mathrm{~m}$ and $21^{\circ} 14^{\prime} 42.6^{\prime \prime} \mathrm{N}, 74^{\circ} 20^{\prime} 59.4^{\prime \prime} \mathrm{W}$ at $1704 \mathrm{~m}$, respectively (Fig. 1). Syringe sampling $(\sim 10 \mathrm{~mL})$ of the upper $\sim 9.5 \mathrm{~m}$ of site SO164-07-4 and $\sim 6.5 \mathrm{~m}$ of site SO164-192 , respectively, took place every $5 \mathrm{~cm}$. Samples taken from the $\sim 2.2 \mathrm{~m}$ of intercalated calcite-turbidite sequences of site SO164-07-4 were discarded.

Selection of Globigerinoides ruber white sensu stricto, Globigerinoides sacculifer, Globorotalia menardii, and Neogloboquadrina dutertrei followed the generic assignments of Kennett and Srinivasan (1983), Hemleben et al. (1989), and Wang (2000). Planktonic foraminiferal specimens resembling G. sacculifer (Brady, 1877) in shape and morphology but without a sac-like final chamber were nominated as Globigerinoides trilobus (Reuss, 1850) in many papers since the 1960s (e.g., Bé and Hamlin, 1967; Hecht, 1974; Lončaríc et al., 2006). On the other hand, both species were lumped in paleoceanographic studies and G. trilobus was assigned to $G$. sacculifer as a morphological variety without sac-like chamber (e.g., Koutavas et al., 2002; Sime et al., 2005). Indeed, culture experiments revealed that the formation of a terminal sac-like chamber in G. sacculifer preceeded gametogenesis, but gametogenesis did also take place without the development of a sac-like chamber. Darkness and the presence of vital symbionts in the cultured specimens had also significant effects on the frequency of sac-like chamber formation (Bé et al., 1982). Considering these experimental data, it is rather unlikely that the G. trilobus morphotype represents an biological entity different from the $G$. sacculifer morphotype. G. sacculifer and their ability to form sac-like chambers evolved after the origin of $G$. trilobus in the early Miocene (Keller, 1981). As such it is justified to determine Pliocene to Holocene specimens with or without a sac-like chamber as G. sacculifer (M. Kucera, Tübingen, personal communication).

\section{$2.1 \delta^{18} \mathrm{O}$ analysis and Element/Ca analysis}

For stable isotope analysis, 10 specimens of planktonic foraminifera $G$. sacculifer (without sac-like final chamber) were selected from the $315-400 \mu \mathrm{m}$ size fraction. All isotope analyses were run on a Finnigan MAT 252 Mass Spectrometer with automated Kiel carbonate preparation device at IFM-GEOMAR (Kiel). The mass spectrometer was calibrated via the National Bureau of Standards (NBS) 19 and an internal laboratory standard to the Vienna Pee Dee Belemnite (PDB) scale. Isotope values are reported in PDB. The external reproducibility of in-house carbonate standards was $\sim 0.08 \%$ o for $\delta^{18} \mathrm{O}$.

Twenty to twenty-five specimens $(\sim 550-800 \mu \mathrm{g})$ of $G$. ruber white, G. sacculifer (without sac-like final chamber), and 
$N$. dutertrei were selected from the $315-400 \mu \mathrm{m}$ size fraction. Clay removal (water and methanol wash) and organicmatter oxidation (hydrogen peroxide treatment) were applied to gently crushed samples, followed by a weak acid leach and final dissolution of the fragments. For detailed description of the Mg-cleaning protocol (Barker et al., 2003), see Regenberg et al. (2006a).

Element/Ca ratios were performed on two inductively coupled plasma optical emission spectrometry (ICP OES) devices showing no significant offsets in $\mathrm{Mg} / \mathrm{Ca}$ (Regenberg et al., 2006a). All G. sacculifer samples, and parts of the G. ruber w. and N. dutertrei samples, were analyzed on an ICP OES (ISA Jobin Yvon, Spex Instruments S.A. GmbH) at IFM-GEOMAR, Kiel, using yttrium (10 ppm) as internal standard. Relative analytical errors for calcium and strontium were $\sim 0.15 \%$, for magnesium $\sim 0.45 \%$, for manganese $\sim 10 \%$, and for iron $\sim 15 \%$. The remainder of the G. ruber w. and $N$. dutertrei samples were measured on an ICP OES (Spectro CirosCCD SOP) at the Institute for Geosciences, Kiel. Relative analytical errors for $\mathrm{Mg} / \mathrm{Ca}$ and $\mathrm{Sr} / \mathrm{Ca}$ ratios were $\sim 0.1 \%$. For manganese and iron, analytical errors amount to $\sim 0.5 \%$ and $\sim 2 \%$, respectively.

\subsection{LA-ICP MS}

For laser ablation inductively coupled plasma mass spectrometry (LA-ICP MS), we selected cleaned G. ruber w., $G$. sacculifer, and N. dutertrei fragments from the 315$400 \mu \mathrm{m}$ size fraction of five different samples. Multiple laser ablation profiles were performed on different foraminiferal fragments from the same sample to elucidate in-test heterogeneities. In total, 18 profiles were ablated.

Using an Excimer $193 \mathrm{~nm}$ deep ultra violet laser (Lambda Physik) with Geolas optics (Günther et al., 1997), craters of $80 \mu \mathrm{m}$ in diameter were ablated during analysis. Energy density at the sample surface was kept at $2 \mathrm{~mJ} / \mathrm{cm}^{2}$, shot repetition rate at $8 \mathrm{~Hz}$. Laser ablation of calcite requires ablation at ultra violet wave lengths since higher wave lengths result in uncontrolled cleavage. The ablated material was transported on a continuous He flow and mixed with an Ar make up gas before injection into the Ar plasma of the quadrupole ICP MS instrument (Micromass Platform at the Faculty of Geosciences, Utrecht University, Netherlands). A collision and reaction cell was used to improve results by reducing spectral interferences on the minor isotopes of $\mathrm{Ca}\left({ }^{42} \mathrm{Ca}\right.$, ${ }^{43} \mathrm{Ca}$, and ${ }^{44} \mathrm{Ca}$ ). Interelemental fractionation was insignificant due to the relative low depth to width ratio of the ablation craters produced (Mason and Mank, 2001). The use of a collision cell also prevented interference of clusters like ${ }^{12} \mathrm{C}^{16} \mathrm{O}^{16} \mathrm{O}$. Although the Excimer UV-193 usually does not show any matrix effects, possible matrix effects, nevertheless, were checked with matrix matched in-house standards. Calibration was performed against U.S. National Institute of Standards and Technology SRM 612 glass using the concentration data of Pearce et al. (1997), with $\mathrm{Ca}$ as an internal standard. Calcium carbonate is well suited for LA-ICP MS because $\mathrm{Ca}$ can be used as an internal standard at 40 weight percentages. We used ${ }^{44} \mathrm{Ca}$ for quantification, ${ }^{42} \mathrm{Ca}$ and ${ }^{43} \mathrm{Ca}$ for internal monitoring. Using $\mathrm{Ca}$ as an internal standard allows direct comparison to trace metal to $\mathrm{Ca}$ ratios from traditional wet-chemical studies. Concentrations of $\mathrm{Mg}$ and $\mathrm{Sr}$ were calculated using ${ }^{24} \mathrm{Mg}$ and ${ }^{26} \mathrm{Mg}$, and ${ }^{88} \mathrm{Sr}$. Although the accuracy for the more abundant ${ }^{24} \mathrm{Mg}$ is higher, both $\mathrm{Mg}$ isotopes agree within a few percent.

With initiation of the ablation process, preferential ablation of material from surfaces that lie orthogonal to the incident laser beam results in greater ablation from the tops of interpore ridges and spine bases (Eggins et al., 2003). This means that the ablation crater is not flat but follows the curvature of the foraminiferal test, and, therefore, should reveal elevated element concentrations in a diagenetic coating when present. Further in the ablation process the craters become increasingly flatter bottomed. This results in a smoothing of the signal when the ablation reaches the pores on the other side of the test. To certify that no smoothing of a possible coating peak occurred, the fragments of each sample were measured both from the inner side toward the outer side and vice versa.

\subsection{Analysis of carbonate phases}

The relative abundance of a variety of minerals present in the sediment samples was quantified by $\mathrm{X}$-ray diffraction (XRD). XRD was typically performed on $\sim 0.5 \mathrm{~g}$ of the bulk sediment. Each sample was carefully grinded for five minutes in an agate mortar in order to homogenize the grain size to $\sim 5-10 \mu \mathrm{m}$. The analysis was carried out on a Philips PW 1710 X-ray diffractometer (IFM-GEOMAR, Kiel) containing a cobalt anode $\mathrm{K} \sigma$ tube at $40 \mathrm{KV}$ and $35 \mathrm{~mA}$. The samples were scanned from $25-40^{\circ}$ at a scanning speed of 0.01 steps per second to cover the significant peaks of the various carbonate minerals. The peak-area method was deployed to quantify the aragonite content using the computer based integration program MacDiff of Petschick (2001). The aragonite/calcite peak-area ratios were converted into relative weight percentages using an in-house calibration curve. Weight percentages of high-magnesium calcite (HMC) and low-magnesium calcite (LMC) were directly calculated from their peak-area ratios.

Weighing of G. sacculifer tests was performed on a Sartorius Micro balance with an error of $\pm 2 \mu \mathrm{g}$. Depending on specimen availability, $\sim 30$ tests per sample from the narrow $355-400 \mu \mathrm{m}$ size fraction were individually weighed to determine robust mean test weights. Mean weights, thus, are considered to represent the populations.

\subsection{Chronostratigraphy}

The stratigraphical framework for the upper $\sim 9.5 \mathrm{~m}$ (including $\sim 2.2 \mathrm{~m}$ of turbidite sediment) of site SO164-07-4 (Fig. 2) 


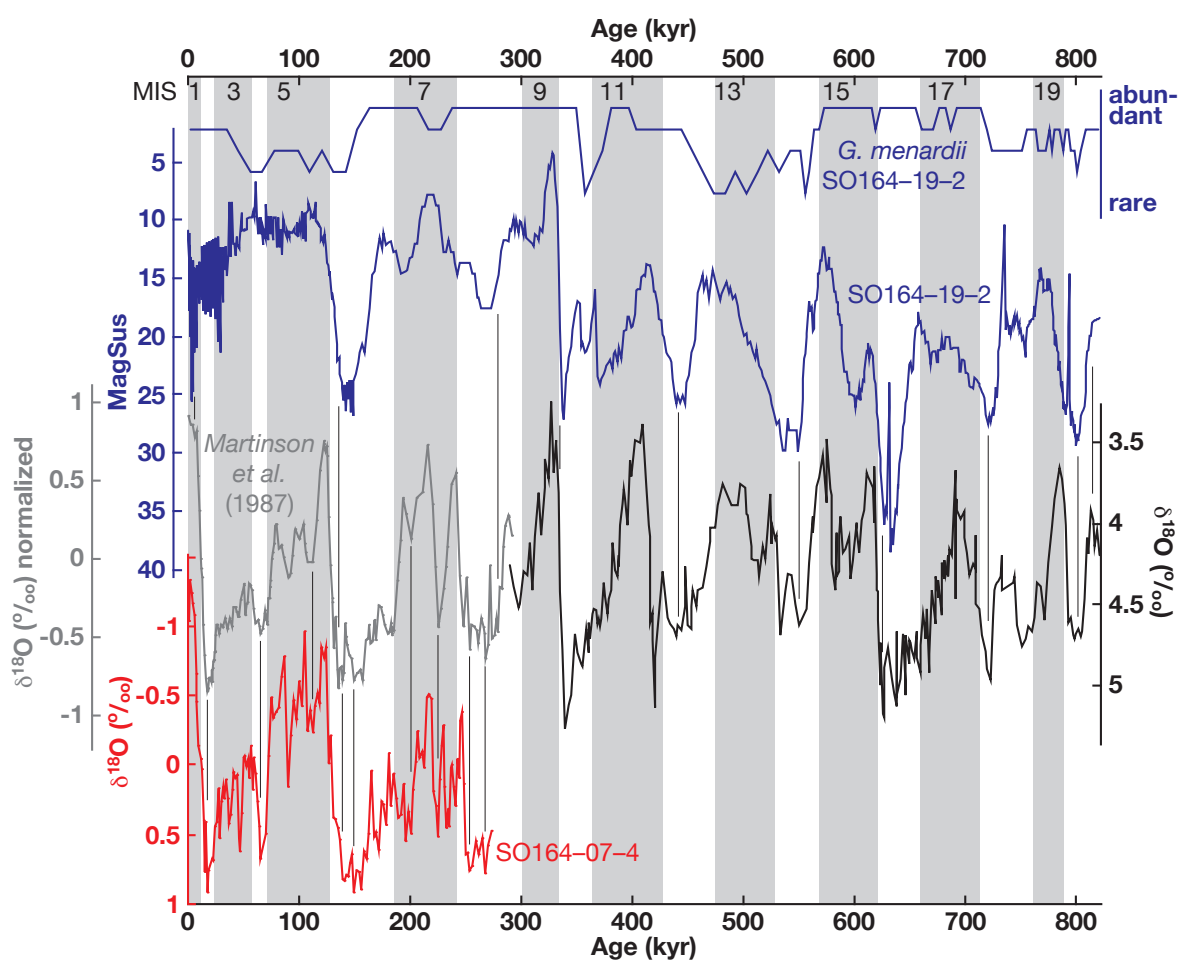

Fig. 2. Stratigraphical framework of sites SO164-07-4 and SO164-19-2 based on the oxygen isotope curve of G. sacculifer and the magnetic susceptibility (MagSus) curve, respectively: For graphical correlation back to 290 ka, the stacked reference curve of Martinson et al. (1987) was used; for the older parts, we used the benthic oxygen isotope record of ODP Site 677 (Shackleton et al., 1990). Tie points are indicated by thin vertical lines. For site SO164-19-2, we additionally estimated the relative abundance of G. menardii as indicator of warm isotope stages. Odd numbered marine isotope stages (MIS) are indicated by shading.

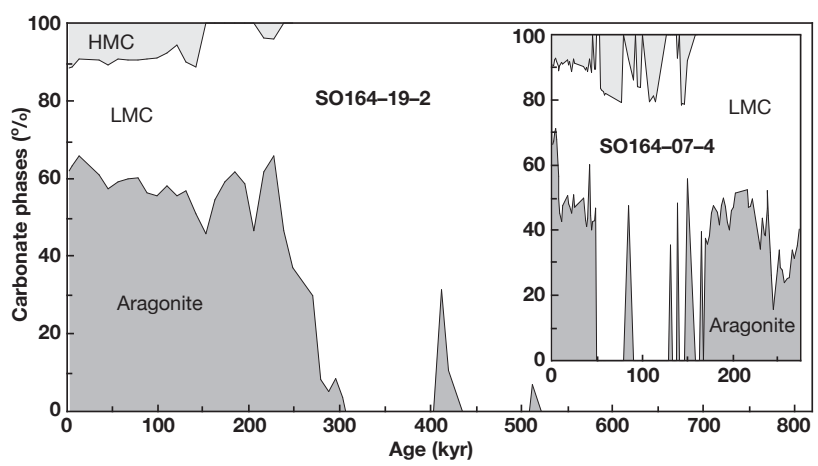

Fig. 3. Carbonate mineralogy of sites SO164-19-2 and SO164-074 (inlet) for the last $\sim 820$ kyrs and $\sim 270$ kyrs, respectively: Proportions of low-magnesium calcite (LMC), high-magnesium calcite (HMC), and aragonite are given in weight \%.

was established by graphically correlating prominent maxima and minima in the planktonic oxygen isotope record of $G$. sacculifer to the stacked reference curve of Martinson et al. (1987). The age model for the upper $\sim 6.5 \mathrm{~m}$ of site SO164-19-2 (Fig. 2) is based on the graphic correlation of the magnetic susceptibility curve younger than $\sim 290 \mathrm{ka}$ with the stacked reference curve of Martinson et al. (1987). For graphical correlation back to $\sim 820 \mathrm{kyrs}$, the magnetic susceptibility curve was correlated to the benthic isotope record of ODP Site 677 (Shackleton et al., 1990). Definition of marine isotope stages (MIS) follows Bassinot et al. (1994), graphic correlation was performed with AnalySeries Version 1.1 (Paillard et al., 1996). To further constrain the chronostratigraphy of site SO164-19-2, we studied the presence/absence of the planktonic foraminifera Globorotalia menardii, serving as time stratigrahic markers and climatic indicators in Pleistocene sediments from the tropical Atlantic (Ericson and Wollin, 1956, 1968; Ruddiman, 1971). Abundance peaks and barren zones correspond, to some extent, with warm and cold marine isotopic stages, respectively (Fig. 2). 


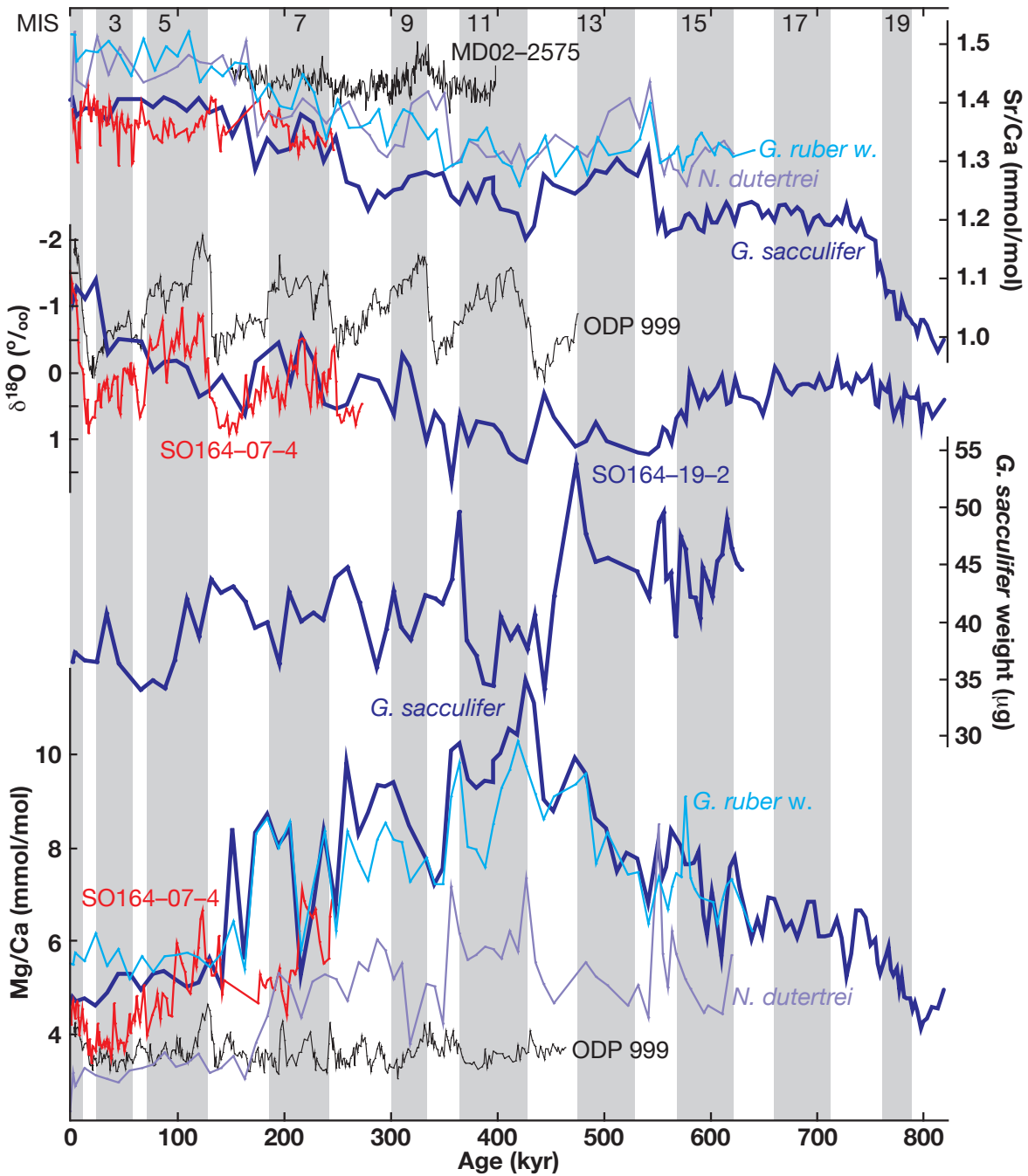

Fig. 4. $\mathrm{Sr} / \mathrm{Ca}$ and $\mathrm{Mg} / \mathrm{Ca}$ curves of G. ruber w., G. sacculifer, and N. dutertrei (top and bottom panels, respectively), and the G. sacculifer oxygen isotope and average test-weight curves of site SO164-19-2 for the last $\sim 820 \mathrm{kyrs}$. The trends of the $\delta^{18} \mathrm{O}$ and $\mathrm{Mg} / \mathrm{Ca}$ records deviate substantially from Caribbean G. ruber w. curves of ODP Site 999 (Schmidt et al., 2006). Likewise, G. ruber w. Sr/Ca is lower than those of G. ruber w. of site MD02-2575 from the Gulf of Mexico (Karas and Nürnberg, Kiel, unpublished data), at least prior to MIS 7. Higher resolution G. sacculifer curves of site SO164-07-4 follow the atypical trends of site SO164-19-2 records.

\section{Results}

\subsection{Carbonate mineralogy}

The composition of the bulk-sediment carbonate of sites SO164-19-2 and SO164-07-4 changes through time (Fig. 3). For site SO164-19-2, the content of HMC (with $\mathrm{Mg}^{2+}$ concentrations $>4 \mathrm{~mol} \%$ (Morse, 2003)) on the carbonate phases amounts to $6-12 \%$ from the core top back until $\sim 140$ kyrs with an additional peak at $\sim 220$ kyrs. From the core top back until $\sim 270 \mathrm{kyrs}$, aragonite contributes with 50 $60 \%$ to the carbonate content. A marked decrease leads to the absence of aragonite (and HMC) from the sediments prior to $\sim 300 \mathrm{kyr}$, except for two aragonite peaks at $\sim 280 \mathrm{kyrs}$ and $\sim 410-420$ kyrs. Higher resolution site SO164-07-4 shows the permanent presence of aragonite and HMC from the core top back until $\sim 48 \mathrm{kyrs}$ at $40-70 \%$ and $7-12 \%$, respectively. Further back to $\sim 116 \mathrm{kyrs}, \mathrm{HMC}$ is present in most of the samples in proportions of $8-21 \%$, while aragonite is only present at $\sim 85$ kyrs. Prior to $\sim 116$ kyrs, HMC is absent except for the time interval of $\sim 139-149$ kyrs. From $\sim 131-$ $169 \mathrm{kyrs}$, aragonite is only present in single peaks, whereas prior to $\sim 169 \mathrm{kyrs}$, aragonite is permanent present in proportions of $16-52 \%$. 


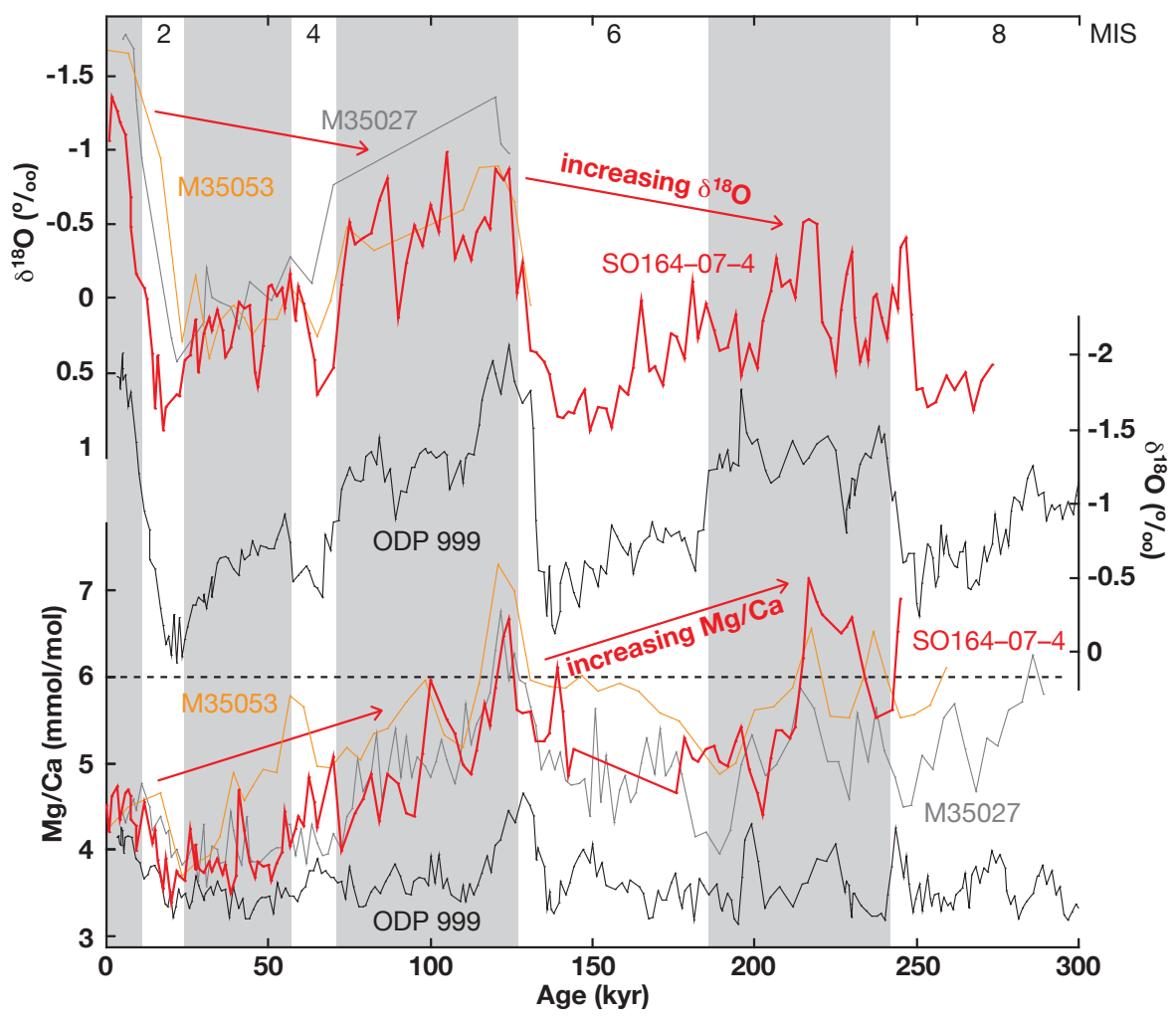

Fig. 5. Oxygen isotope and Mg/Ca curves of G. sacculifer of site SO164-07-4 for the last $~ 250$ kyrs: For comparison, Caribbean G. sacculifer curves of sites M35027 and M35053 (Müller, 1999), and G. ruber w. curves of ODP Site 999 (Schmidt et al., 2006) are given. Increased $\delta^{18} \mathrm{O}$ and anomalously high $\mathrm{Mg} / \mathrm{Ca}$ with respect to Holocene values at least during MIS 5 and 7 of sites SO164-07-4, M35027, and M35053 do not follow the expected trend observed for ODP Site 999 . Note that $\mathrm{Mg} / \mathrm{Ca}$ of $>6 \mathrm{mmol} / \mathrm{mol}$ would convert to open-ocean temperatures of $>30.5^{\circ} \mathrm{C}$.

\section{$3.2 \delta^{18} \mathrm{O}, \mathrm{Mg} / \mathrm{Ca}$, and $\mathrm{Sr} / \mathrm{Ca}$ records of sites $\mathrm{SO} 164-19-2$ and SO164-07-4}

The $\delta^{18} \mathrm{O}, \mathrm{Mg} / \mathrm{Ca}$, and $\mathrm{Sr} / \mathrm{Ca}$ records of sites SO164-19-2 and SO164-07-4 reveal atypical patterns compared to proxy records from adjacent areas available in the literature (e.g., Curry and Oppo, 1997; Schmidt et al., 2006). Site SO16419-2 covers the glacial/interglacial cycles back to $\sim 820 \mathrm{kyrs}$ in low resolution (Fig. 4). Core top, Holocene, and interglacial isotope stage $\delta^{18} \mathrm{O}$ are consistent with the corresponding values of site SO164-07-4. Reaching values as high as 1.62 and prior to MIS 3 not lower than about $-0.5 \%$ o, $\delta^{18} \mathrm{O}$ is far offset from the Caribbean ODP Site $999 \delta^{18} \mathrm{O}$ record of G. ruber w. (Schmidt et al., 2006) showing highest values of $\sim 0.1$ during MIS 2 and MIS 12 (Fig. 4). From MIS 1420 , variation in $\delta^{18} \mathrm{O}$ is considerably dampened, values are around $0.5 \%$.

$\mathrm{Mg} / \mathrm{Ca}$ of site SO164-19-2 shows a completely different trend compared to the G. ruber w. record of ODP Site 999 (Schmidt et al., 2006). Expected lower $\mathrm{Mg} / \mathrm{Ca}$ during MIS 24 with respect to core-top and Holocene ratios are not observed (Fig. 4). From G. ruber w. $\mathrm{Mg} / \mathrm{Ca}$ of $\sim 5.5 \mathrm{mmol} / \mathrm{mol}$ during this time interval and throughout MIS 5, an intense increase to ratios $>8 \mathrm{mmol} / \mathrm{mol}$ occurs during MIS 6 . Among a large variability of $\sim 3 \mathrm{mmol} / \mathrm{mol}, \mathrm{Mg} / \mathrm{Ca}$ further increases to $>10 \mathrm{mmol} / \mathrm{mol}$ during MIS $10-12$. This trend is also reflected in the $\mathrm{Mg} / \mathrm{Ca}$ records of $G$. sacculifer and $N$. dutertrei of site SO164-19-2 (Fig. 4), whereas the latter is almost constantly offset by $\sim 2.5-3 \mathrm{mmol} / \mathrm{mol}$ to lower ratios. Decreasing $\mathrm{Mg} / \mathrm{Ca}$ particularly during MIS 13 level off the ratios of G. sacculifer to $\sim 6-7 \mathrm{mmol} / \mathrm{mol}$ during MIS $16-18$. Lower ratios than core-top $\mathrm{Mg} / \mathrm{Ca}$ are observed for MIS 20. Comparing the younger part of the record to the G. sacculifer $\mathrm{Mg} / \mathrm{Ca}$ of site SO164-07-4, a similar trend at least during MIS 5 and MIS 7 as compared to the G. sacculifer and G. ruber w. records of site SO164-19-2 can be seen (Fig. 4).

G. sacculifer $\mathrm{Sr} / \mathrm{Ca}$ ratios of $\sim 1.4 \mathrm{mmol} / \mathrm{mol}$ are observed back until MIS 7 with excursions to $\sim 1.3 \mathrm{mmol} / \mathrm{mol}$ during MIS 6. A similar trend is shown by the G. sacculifer $\mathrm{Sr} / \mathrm{Ca}$ curve of site SO164-07-4. During MIS 8, Sr/Ca decreases to ratios of $\sim 1.25-1.3 \mathrm{mmol} / \mathrm{mol}$. This level persists until MIS 14 with excursions to minimum ratios of $\sim 1.2 \mathrm{mmol} / \mathrm{mol}$. During MIS $14, \mathrm{Sr} / \mathrm{Ca}$ decreases to a level 

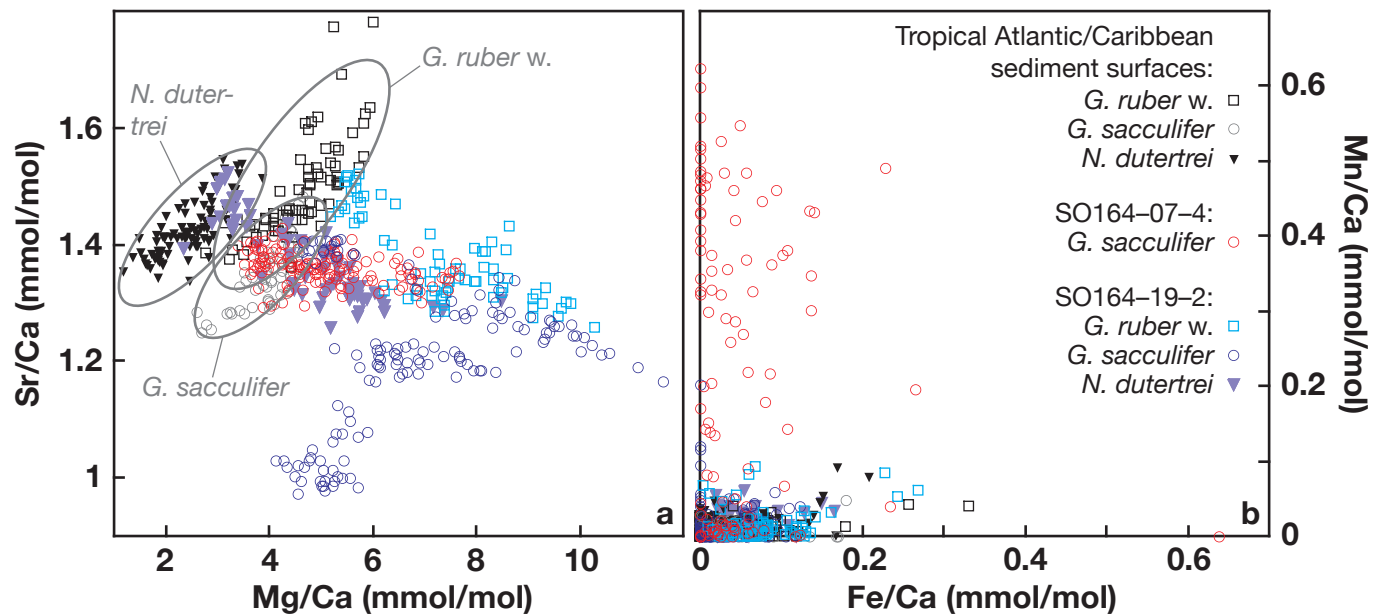

Fig. 6. (a) $\mathrm{Mg} / \mathrm{Ca}$ versus $\mathrm{Sr} / \mathrm{Ca}$ ratios and (b) $\mathrm{Fe} / \mathrm{Ca}$ versus $\mathrm{Mn} / \mathrm{Ca}$ ratios of sediment-surface (black and grey symbols) and downcore G. ruber w., G. sacculifer, and N. dutertrei (colored symbols). Marked elliptical areas characterize the modern $\mathrm{Mg} / \mathrm{Ca}$ and $\mathrm{Sr} / \mathrm{Ca}$ of tropical Atlantic/Caribbean sediment-surface samples, which resemble open-ocean temperatures of $\sim 19-28^{\circ} \mathrm{C}$ (Regenberg et al., 2006a; Regenberg et al., 2006 $\left.{ }^{1}\right)$. Related low $\mathrm{Fe} / \mathrm{Ca}(\sim 0.2 \mathrm{mmol} / \mathrm{mol})$ and $\mathrm{Mn} / \mathrm{Ca}(\sim 0.1 \mathrm{mmol} / \mathrm{mol})$, unanimously obtained for the core-top foraminifera, indicate that contaminating phases other than carbonate can be neglected as source of $\mathrm{Mg}^{2+}$ at least for site SO164-19-2. Annotation of (a) is the same as for (b).

Regenberg, M., Steph, S., Nürnberg, D., Tiedemann, R., and Mulitza, S.: Calibrating Mg/Ca of Multiple Planktonic Foraminiferal Species with $\delta^{18}$ O-Calcification Temperatures: Paleothermometry for the Upper Water Column, Earth Planet. Sci. Lett., submitted, EPSL-D-06-00991, 2006b.

of $\sim 1.2 \mathrm{mmol} / \mathrm{mol}$. In the oldest parts, $\mathrm{Sr} / \mathrm{Ca}$ further decreases to ratios $<1 \mathrm{mmol} / \mathrm{mol}$. For the entire record, $\mathrm{Sr} / \mathrm{Ca}$ of G. ruber w. and N. dutertrei of site SO164-19-2 are offset to higher ratios by $\sim 0.5-1 \mathrm{mmol} / \mathrm{mol}$ and follow the trend of $G$. sacculifer. The decreasing trend in all planktonic foraminiferal $\mathrm{Sr} / \mathrm{Ca}$ records prior to MIS 6 contradicts the $G$. ruber w. Sr/Ca record of site MD02-2575 from the Gulf of Mexico (data obtained from Cyrus Karas and Dirk Nürnberg, Kiel, unpublished data), which remains at the same level of $\sim 1.4-1.5 \mathrm{mmol} / \mathrm{mol}$ from MIS 6-11.

The average test weight of $G$. sacculifer from site SO16419-2 generally shows an increasing trend with time. From $\sim 33-40 \mu \mathrm{g}$ in the youngest part, weights increase to $\sim 36$ $45 \mu \mathrm{g}$ in the interval between MIS $6-10$ and to $\sim 38-50 \mu \mathrm{g}$ prior to MIS 12 (Fig. 4). Very high (low) $\mathrm{Mg} / \mathrm{Ca}(\mathrm{Sr} / \mathrm{Ca})$ at transitions MIS 10/11 and MIS 12/13 are coinciding with highest test weights of $\sim 50 \mu \mathrm{g}$ and $\sim 55 \mu \mathrm{g}$, respectively. Yet, MIS 11 and 12, characterized by highest (very low) $\mathrm{Mg} / \mathrm{Ca}(\mathrm{Sr} / \mathrm{Ca})$, are accompanied by very low test weights of only $\sim 34-41 \mu \mathrm{g}$.

\subsection{Atypical trends in Caribbean $\delta^{18} \mathrm{O}$ and $\mathrm{Mg} / \mathrm{Ca}$ records}

The G. sacculifer $\delta^{18} \mathrm{O}$ record of site SO164-07-4 shows two complete glacial cycles back to MIS 8 at $\sim 270$ kyrs (Figs. 2, 5). $\quad \delta^{18} \mathrm{O}$ values across Terminations I and II display glacial/interglacial differences of $\sim 2.2 \%$ and $\sim 1.6 \%$, respectively. Other (sub)tropical Atlantic, Caribbean, and Bahamian records (Curry and Oppo, 1997; Wolff et al., 1998;
Rühlemann et al., 1999; Kroon et al., 2000; Schmidt et al., 2004, 2006), in contrast, indicate that differences across both terminations are similar. The difference across Termination III of $\sim 1.2 \%$ o better matches with the range of $\sim 1.1 \%$ o observed for Caribbean ODP Site 999 (Schmidt et al., 2006) (Fig. 5). The Holocene attains minimum $\delta^{18} \mathrm{O}$ of about $-1.5 \%$, which is exceeded in interglacial MIS 5 and MIS 7 with values of about $-1.0 \%$ and $-0.5 \%$, respectively. In contrast to other studies (Kroon et al., 2000; Schmidt et al., 2006), the Holocene stands out in the record with the most negative $\delta^{18} \mathrm{O}$ values. Highest values during glacial MIS 2, MIS 6, and MIS 8 are close to $0.9 \%$. In lower resolution, the $G$. sacculifer $\delta^{18} \mathrm{O}$ records of sites M35027 and M35053 (Müller, 1999) go back to MIS 5, with more depleted Holocene values than site SO164-07-4, but with similar increased values during MIS 5 (Fig. 5).

Mean Holocene G. sacculifer $\mathrm{Mg} / \mathrm{Ca}$ yields $\sim 4.5 \mathrm{mmol} / \mathrm{mol}$ (Fig. 5). Such $\mathrm{Mg} / \mathrm{Ca}$ corresponds to reasonable temperatures of $\sim 27.0^{\circ} \mathrm{C}$, when applying the paleotemperature equation of Anand et al. (2003). Mg/Ca of site SO164-07-4 decreases to $\sim 3.7 \mathrm{mmol} / \mathrm{mol}\left(\sim 24.4^{\circ} \mathrm{C}\right)$ during the Last Glacial Maximum (LGM, 18-24 kyr). This Holocene/LGM change in $\mathrm{Mg} / \mathrm{Ca}$ of $\sim 0.8 \mathrm{mmol} / \mathrm{mol}$ is consistent with previous estimates for the Caribbean (Hastings et al., 1998; Schmidt et al., 2004, 2006). From the Holocene to MIS 3, Mg/Ca of site SO164-07-4 is nearly parallel offset by $\sim 0.2 \mathrm{mmol} / \mathrm{mol}$ from the $G$. ruber w. record of Caribbean ODP Site 999 (Schmidt et al., 2004, 2006). Prior to MIS 4, $\mathrm{Mg} / \mathrm{Ca}$ reveals lowest values of $\sim 5 \mathrm{mmol} / \mathrm{mol}$. From this 

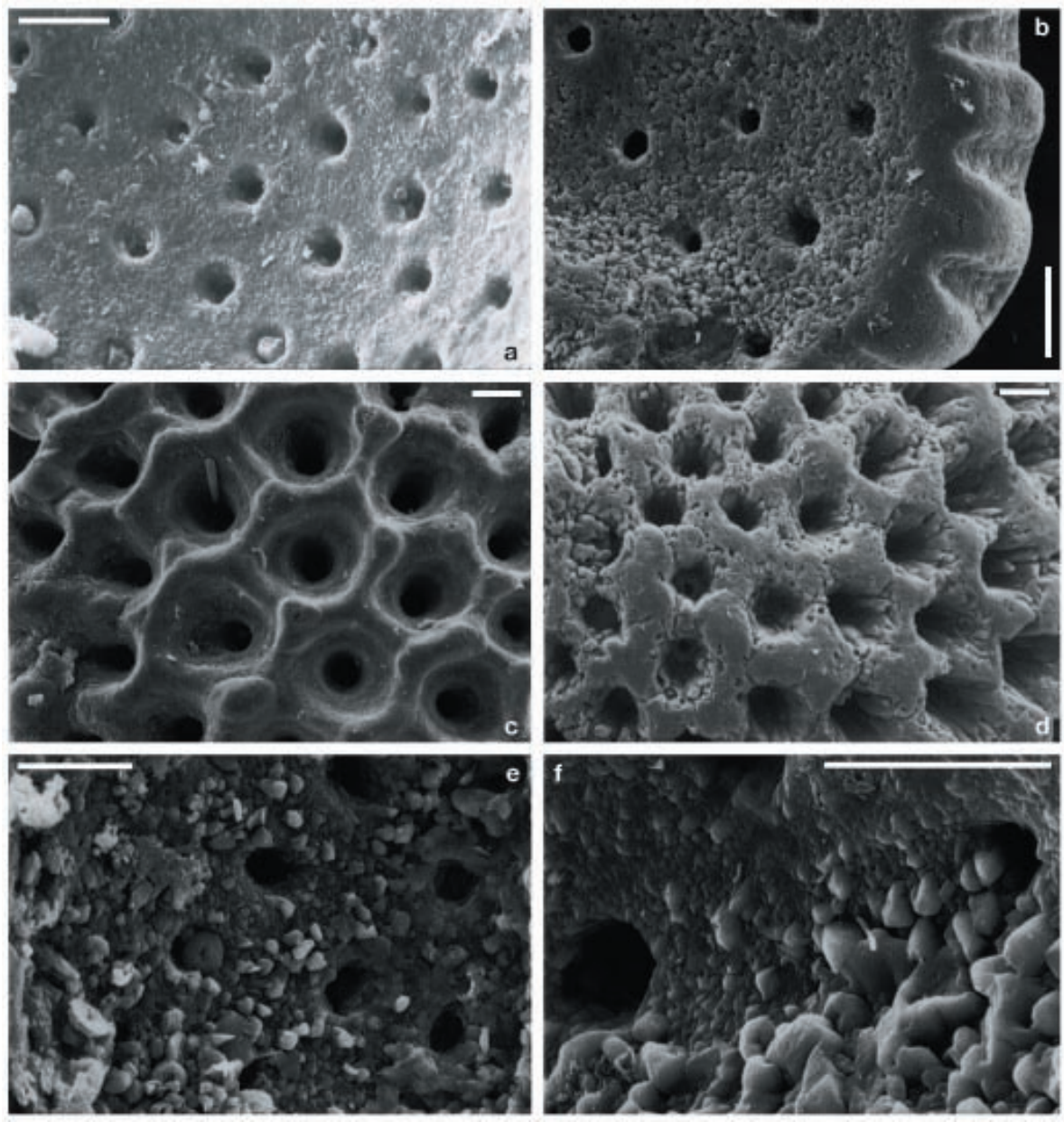

Fig. 7. SEM images of the wall-surface texture of opened planktonic foraminiferal chambers: (a) G. ruber w. of site SO164-07-4, 118 cm ( $\sim 23 \mathrm{kyrs}$ ) with typical Mg/Ca, uncleaned; (b) G. ruber w. of site SO164-19-2, $130 \mathrm{~cm}(\sim 259.5 \mathrm{kyrs})$ with anomalous Mg/Ca, cleaned; (c) G. sacculifer of site SO164-07-4, $118 \mathrm{~cm}(\sim 23 \mathrm{kyrs})$ with typical Mg/Ca, cleaned; (d) G. ruber w. of site SO164-19-2, 260 cm ( $473 \mathrm{kyrs)}$ with anomalous $\mathrm{Mg} / \mathrm{Ca}$, cleaned; (e and f) $N$. dutertrei of site SO164-19-2, $315 \mathrm{~cm}$ ( $\sim 563.5 \mathrm{kyrs})$ with anomalous $\mathrm{Mg} / \mathrm{Ca}$, uncleaned and cleaned, respectively. Mg-cleaned samples, whether with or without overgrowth, show smoothed edges due to the intense cleaning protocol. Scale bar $=10 \mu \mathrm{m}$.

level, $\mathrm{Mg} / \mathrm{Ca}$ increases to as much as $6.66 \mathrm{mmol} / \mathrm{mol}$ during MIS 5e and $7.13 \mathrm{mmol} / \mathrm{mol}$ during MIS 7, corresponding to temperatures of $\sim 32.2^{\circ} \mathrm{C}$ and $\sim 33.1^{\circ} \mathrm{C}$, respectively, which approaches the upper temperature tolerance of these species (Bijma et al., 1990). Prior to MIS 4, Mg/Ca diverges from the ratios of ODP Site 999 (Schmidt et al., 2006). During MIS 5, MIS 6, and late MIS 7, the offset amounts to $\sim 1.5-$ $2 \mathrm{mmol} / \mathrm{mol}$, increasing to $\sim 3 \mathrm{mmol} / \mathrm{mol}$ for the oldest parts. The Mg/Ca records of sites M35027 and M35053 (Müller, 1999) generally show the same atypical trend like those of site SO164-07-4. In general, the downcore increasing trend in $\delta^{18} \mathrm{O}$, obviously for the interglacials, is synchronized to the increasing trend in $\mathrm{Mg} / \mathrm{Ca}$ (Fig. 5).
3.4 Negligible influence of contaminating phases on $\mathrm{Mg} / \mathrm{Ca}$ ratios

With respect to the $\mathrm{Mg} / \mathrm{Ca}$ and $\mathrm{Sr} / \mathrm{Ca}$ ratios of tropical Atlantic and Caribbean sediment-surface samples (Regenberg et al., 2006a), downcore records of sites SO164-07-4 and SO164-19-2 reveal elevated $\mathrm{Mg} / \mathrm{Ca}$ and lowered $\mathrm{Sr} / \mathrm{Ca}$ (Fig. 6a). To evaluate the possible contribution of contaminating phases high in magnesium, iron, and/or manganese (i.e. clay minerals, Mn-oxide coatings) to the original planktonic foraminiferal $\mathrm{Mg} / \mathrm{Ca}$ and $\mathrm{Sr} / \mathrm{Ca}$, we measured the $\mathrm{Fe} / \mathrm{Ca}$ and $\mathrm{Mn} / \mathrm{Ca}$ ratios of our foraminiferal sample solutions. These phases may coat or adhere to the surfaces of tests. Barker et al. (2003) found $\mathrm{Fe} / \mathrm{Ca}$ and $\mathrm{Mn} / \mathrm{Ca}$ of around $0.2 \mathrm{mmol} / \mathrm{mol}$ and $0.1 \mathrm{mmol} / \mathrm{mol}$, respectively, typically for 

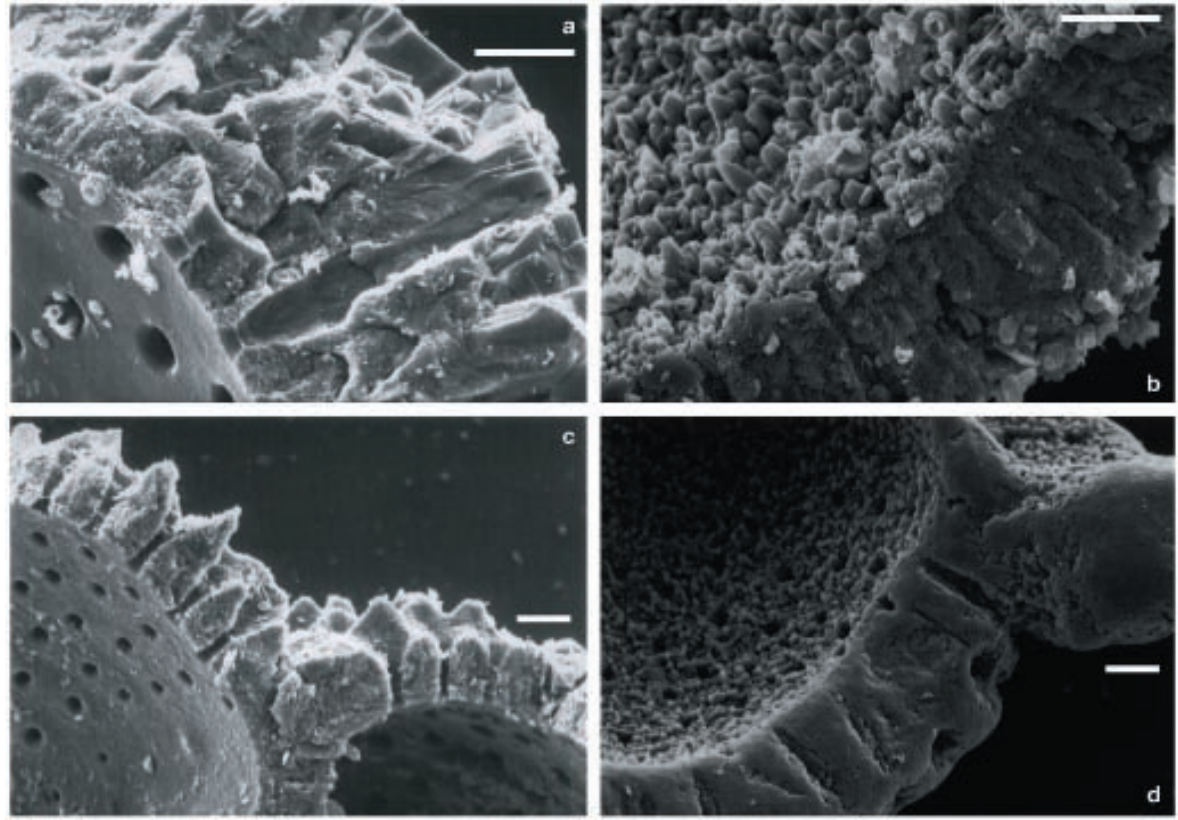

Fig. 8. SEM images of wall-cross sections of opened planktonic foraminiferal chambers: (a) $N$. dutertrei of site SO164-07-4, 3 cm ( $\sim 0.9 \mathrm{kyrs})$ with typical Mg/Ca, uncleaned; (b) G. ruber w. of site SO164-19-2, $260 \mathrm{~cm}(\sim 473 \mathrm{kyrs})$ with anomalous $\mathrm{Mg} / \mathrm{Ca}$, uncleaned; (c) G. ruber w. of site SO164-07-4, $3 \mathrm{~cm}(\sim 0.9 \mathrm{kyrs})$ with typical Mg/Ca, uncleaned; (d) G. ruber w. of site SO164-19-2, 260 cm ( $473 \mathrm{kyrs})$ with anomalous $\mathrm{Mg} / \mathrm{Ca}$, cleaned. Scale bar $=10 \mu \mathrm{m}$.

foraminiferal tests devoid of contaminating phases. These ratios, which imply negligible elevation of $\mathrm{Mg} / \mathrm{Ca}$, are observed for the sediment-surface and site SO164-19-2 samples (Fig. 6b). For site SO164-07-4, elevated foraminiferal $\mathrm{Mn} / \mathrm{Ca}$ of up to $0.6 \mathrm{mmol} / \mathrm{mol}$ may be indicative of contamination by Mn-oxide coatings. The suggested contribution of $\mathrm{Mg}^{2+}$ from coatings to the foraminiferal $\mathrm{Mg} / \mathrm{Ca}$ of $\sim 1 \%$ (Barker et al., 2003), however, cannot account alone for the atypically high $\mathrm{Mg} / \mathrm{Ca}$ (up to $7.13 \mathrm{mmol} / \mathrm{mol}$ ) of site SO16407-4 (Fig. 6a).

3.5 Micro-scale crystallites on planktonic foraminiferal tests

In order to understand the geochemical composition of the planktonic foraminiferal tests atypically for open-ocean conditions (Figs. 4, 5, 6a), we prepared scanning electron microscope (SEM) images of selected cleaned and uncleaned fragments of specimens revealing typical $\mathrm{Mg} / \mathrm{Ca}$ ratios and anomalously high $\mathrm{Mg} / \mathrm{Ca}$, respectively. Tests of those specimens revealing typical $\mathrm{Mg} / \mathrm{Ca}$ (Fig. 7a, c) show inner and outer chamber-wall surfaces of well preserved biogenic texture with smooth surfaces, wide pores, and well defined outer ridges. In contrast, surfaces of those specimens revealing anomalously high $\mathrm{Mg} / \mathrm{Ca}$ (Fig. 7) are overgrown with microscale euhydral crystallites of secondary precipitates, which cover the outer ridges and fill the pores. The diagenetic overgrowth covers the inner surface even after the intense Mg-cleaning procedure. SEM images of chamber-wall cross sections of specimens without overgrowth display the microgranular texture that is characteristic of biogenic calcite. The intact wall structure comprises wide pores reaching throughout the wall and smooth inner surfaces (Fig. 8a, c). Chamberwall cross sections of specimens with overgrowths reveal that the crystallites narrow the pores and almost close them at their insides (Fig. 8). Figure 8b displays an uncleaned fragment identifying the diagenetic crystallites as distinct rims with a sharply bordered contact to the biogenic calcite.

\subsection{Geochemical composition of the diagenetic overgrowth}

To further constrain the possible influence of the crystallites on the planktonic foraminiferal geochemistry, we analyzed the elemental composition of foraminiferal chamber walls of site SO164-19-2 applying LA-ICP MS. Since single laser pulses remove only a few nanometers of material the ablation results in a high resolution profile. We observed a significantly different $\mathrm{Mg} / \mathrm{Ca}$ and $\mathrm{Sr} / \mathrm{Ca}$ signal for the outermost proportions compared to the remainder of the chamber walls (Fig. 9). Whether close to the inner or outer surfaces, $\mathrm{Mg} / \mathrm{Ca}$ ratios are 4-6 times elevated and $\mathrm{Sr} / \mathrm{Ca} 2$ 3 times depleted with respect to the profile averages. For the time interval of $\sim 260-470 \mathrm{kyrs}$, chamber-wall surface $\mathrm{Mg} / \mathrm{Ca}$ is at least $10 \mathrm{mmol} / \mathrm{mol}$ (highest observed ratios are 
Table 1. Mass-balanced $\mathrm{Mg} / \mathrm{Ca}$ and $\mathrm{Sr} / \mathrm{Ca}$ ratios of an assumed planktonic foraminiferal sample overgrown with diagenetic crystallites. Proportions of overgrowth are given with respect to foraminiferal calcite. Assumed crystallite ratios are obtained from LA-ICP MS results.

\begin{tabular}{cccccc}
\hline $\begin{array}{c}\text { Over- } \\
\text { growth } \\
\%\end{array}$ & \multicolumn{5}{c}{$\begin{array}{c}\text { Combined signature of planktonic } \\
\text { foraminifera and overgrowth }(\mathrm{mmol} / \mathrm{mol})\end{array}$} \\
\hline${ }^{\mathrm{a}} \mathrm{Mg} / \mathrm{Ca}$ & ${ }^{\mathrm{b}} \mathrm{Mg} / \mathrm{Ca}$ & ${ }^{\mathrm{c}} \mathrm{Mg} / \mathrm{Ca}$ & ${ }^{\mathrm{d}} \mathrm{Sr} / \mathrm{Ca}$ & ${ }^{\mathrm{e}} \mathrm{Sr} / \mathrm{Ca}$ \\
\hline 5 & 4.0 & 4.0 & 4.0 & 1.40 & 1.40 \\
10 & 4.3 & 4.8 & 5.8 & 1.36 & 1.37 \\
15 & 4.6 & 5.6 & 7.6 & 1.31 & 1.34 \\
20 & 5.9 & 6.4 & 9.4 & 1.27 & 1.31 \\
\hline
\end{tabular}

a Assumed $\mathrm{Mg} / \mathrm{Ca}(\mathrm{mmol} / \mathrm{mol})$ :

Planktonic foraminifera $=4$; crystallites $=10$

${ }^{\mathrm{b}}$ Assumed $\mathrm{Mg} / \mathrm{Ca}(\mathrm{mmol} / \mathrm{mol})$ :

Planktonic foraminifera $=4$; crystallites $=20$

c Assumed $\mathrm{Mg} / \mathrm{Ca}(\mathrm{mmol} / \mathrm{mol})$ :

Planktonic foraminifera $=4$; crystallites $=40$

d Assumed $\mathrm{Sr} / \mathrm{Ca}(\mathrm{mmol} / \mathrm{mol})$ :

Planktonic foraminifera $=1.4$; crystallites $=0.5$

e Assumed $\mathrm{Sr} / \mathrm{Ca}(\mathrm{mmol} / \mathrm{mol})$ :

Planktonic foraminifera $=1.4$; crystallites $=0.8$

$>40 \mathrm{mmol} / \mathrm{mol}$; Fig. 9), Sr/Ca shows relatively uniform ratios of $\sim 0.5-0.8 \mathrm{mmol} / \mathrm{mol}$ (Fig. 10).

\section{Discussion}

The $\delta^{18} \mathrm{O}, \mathrm{Mg} / \mathrm{Ca}$, and $\mathrm{Sr} / \mathrm{Ca}$ records of downcore planktonic foraminiferal samples of sites SO164-07-4 and SO164-19-2 show to some extent atypical values with respect to previously published data sets supposed to reflect past environmental conditions (Figs. 4, 5). Within the same samples, $\delta^{18} \mathrm{O}$ as well as $\mathrm{Mg} / \mathrm{Ca}$ are higher than expected, $\mathrm{Sr} / \mathrm{Ca}$, contrarily, shows the inverse trend with lower ratios than expected.

In principal, the oxygen isotope composition of the actual planktonic foraminiferal test is determined by the $\delta^{18} \mathrm{O}$ composition and (higher) temperature of the pelagic waters, in which the calcite was formed. Since precipitation of the overgrowth during diagenesis is expected to occur near the sediment/bottom-water interface and its oxygen isotope composition is driven by thermodynamic fractionation (e.g., O’Neil et al., 1969; Kim and O'Neil, 1997), $\delta^{18} \mathrm{O}$ tends to more positive values (e.g., Killingley, 1983; Schrag et al., 1995; Crowley and Zachos, 2000; Pearson et al., 2001; Wade and Kroon, 2002). Like in this study, higher than expected foraminiferal $\delta^{18} \mathrm{O}$ from deep-sea sites in conjunction with diagenetic crystalline overgrowth has been observed, yet merely for sample material from greater sediment-burial depth (e.g., Pearson et al., 1997; Norris and Wilson, 1998;
Price et al., 1998; Wade and Kroon, 2002; Tripati et al., 2003; Sexton et al., 2006).

The common approach to understand the contribution to the calcite composition derived from inorganic precipitates is using downcore pore-fluid data for the calculation and numerical modeling of theoretical precipitate compositions (e.g., Killingley, 1983; Schrag et al., 1992; Schrag, 1999; Rudnicki et al., 2001; Tripati et al., 2003; Sexton et al., 2006). In contrast to these studies, we attempt to quantify the influence of the diagenetic overgrowth with the results from laser-ablation analysis, as downcore pore fluid data are not available for the presented sites and the fluid behavior at the very shallow burial depth of the deep-sea sediments is hardly understood (e.g., Mullins et al., 1985; Morse, 2003).

4.1 $\mathrm{Mg} / \mathrm{Ca}$ and $\mathrm{Sr} / \mathrm{Ca}$ data: Assessing the extent of diagenetic alteration

Considering the visual evidence for diagenetic alteration of planktonic foraminiferal tests (Figs. 7, 8) in combination with the results of the laser ablation (Figs. 9, 10), anomalously high $\mathrm{Mg} / \mathrm{Ca}$ is best explained by the presence of inorganic calcite: The outermost measurements, even if timeresolved, closely correspond with the outermost position of the diagenetic crystallites. Inorganic calcite contains about an order of magnitude more $\mathrm{Mg}^{2+}$ than planktonic foraminiferal calcite (e.g., Katz, 1973; Baker et al., 1982; Mucci and Morse, 1983; Mucci, 1987). We detected 10$40 \mathrm{mmol} / \mathrm{mol}$ for the crystallites and typically $<7 \mathrm{mmol} / \mathrm{mol}$ for the actual test (Figs. 9, 10). Thus, only a limited amount of overgrowth remaining on the foraminiferal test after the $\mathrm{Mg}$-cleaning procedure, would be sufficient to raise $\mathrm{Mg} / \mathrm{Ca}$ of bulk sample calcite.

$\mathrm{Sr} / \mathrm{Ca}$ of the ablated chamber-wall cross sections reveals $2-3$ times depleted ratios for the inorganic crystallites $(\sim 0.5-$ $0.8 \mathrm{mmol} / \mathrm{mol}$; Figs. 9, 10). Depending on the species, typical $\mathrm{Sr} / \mathrm{Ca}$ of recent core-top planktonic foraminifera without overgrowth are in the order of $1.2-1.7 \mathrm{mmol} / \mathrm{mol}$ (Fig. 6), which is in good agreement with literature specifications (e.g., Lea et al., 1999; Russell et al., 2004; Elderfield et al., 2000; Kunioka et al., 2006). In general, foraminiferal calcite is supposed to record $\mathrm{Sr} / \mathrm{Ca}$ of seawater (Delaney et al., 1985), which changes on glacial/interglacial time scales (e.g., Graham et al., 1982; Stoll and Schrag, 1998). Sr/Ca is relatively homogeneously distributed throughout the test (e.g., Brown and Elderfield, 1996; Anand and Elderfield, $2005)$ and is affected by other factors like temperature, $\mathrm{pH}$, and salinity with an absolute $\mathrm{Sr} / \mathrm{Ca}$ variation of $\sim 15 \%$ (Lea et al., 1999; Russell et al., 2004; Anand and Elderfield, 2005; Kunioka et al., 2006). However, since biogenic calcite contains significantly more $\mathrm{Sr}^{2+}$ than inorganic (Baker et al., 1982; Carpenter and Lohmann, 1992), the low Sr/Ca observed in this study indicates significant proportions of secondary inorganic calcite attached to the foraminiferal test (Bralower et al., 1997). 

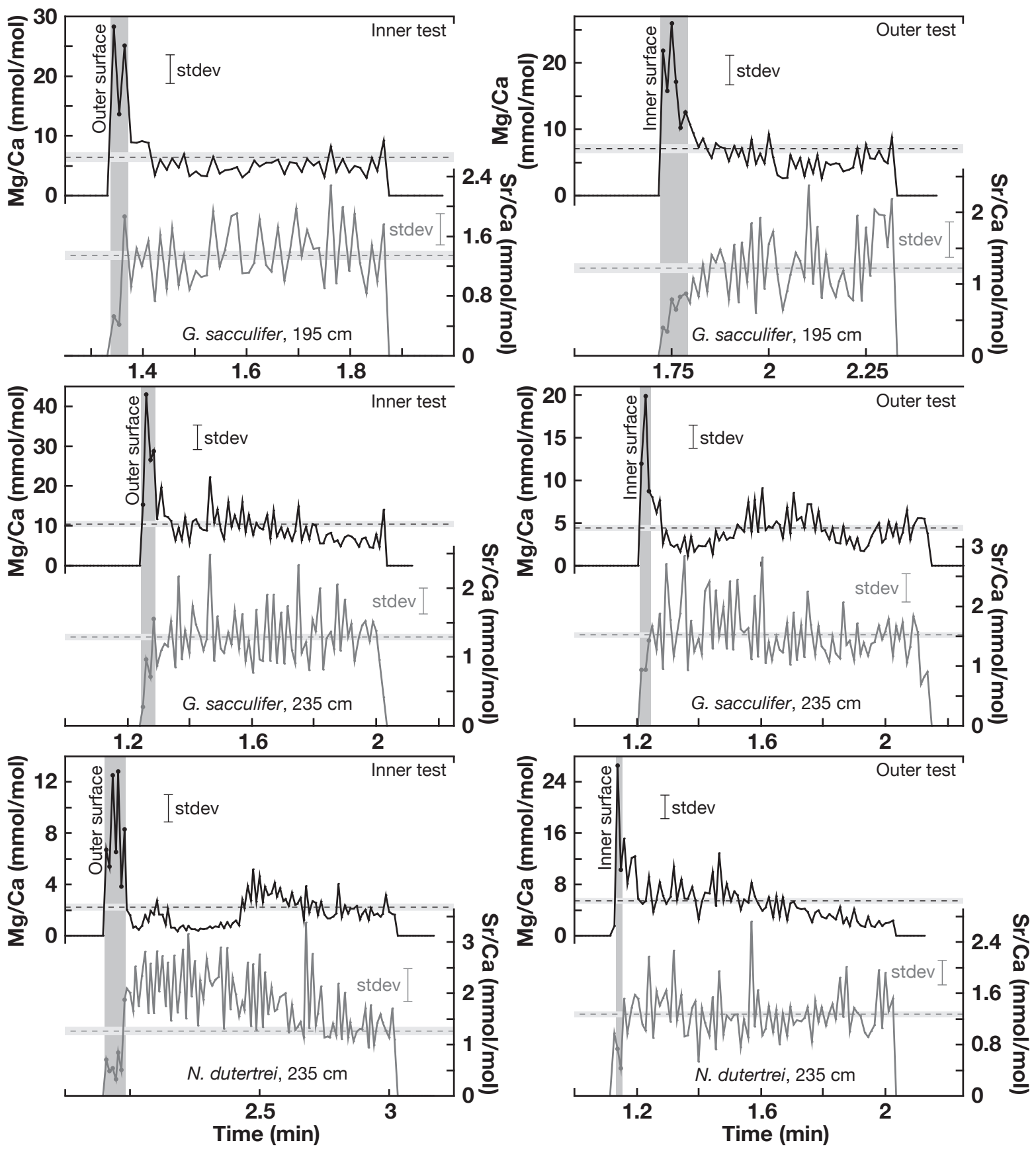

Fig. 9. Time-resolved LA-ICP MS Mg/Ca (upper panels) and $\mathrm{Sr} / \mathrm{Ca}$ ratios (lower panels) of cleaned foraminiferal samples with diagenetic overgrowths of site SO164-19-2, ablated perpendicular to the chamber-wall surfaces: Sample $195 \mathrm{~cm}(\sim 365 \mathrm{kyrs})$, sample $235 \mathrm{~cm}$ ( $\sim 27 \mathrm{kyrs})$. Standard deviations of single ratios are given as error bars (stdev). Horizontal dashed lines illustrate mean ratios averaged for the entire profile of each plot, standard deviations of the respective means are given as horizontal bars. Vertical grey bars illustrate surfacenear ratios revealing elevated $\mathrm{Mg} / \mathrm{Ca}$ and lowered $\mathrm{Sr} / \mathrm{Ca}$ compared to the remainder ratios. Left hand profiles are ablated from the outer side of the tests towards the inner side, right hand profiles vice versa.

Tests of the same species and size are assumed to have relatively constant initial weights before sinking to the seafloor (e.g., Barker and Elderfield, 2002). Decreasing test weight is positively correlated with the seawater carbonate ion concentration (e.g., Lohmann, 1995; Broecker and Clark, 2001) and accompanied by changing geochemical composition of 

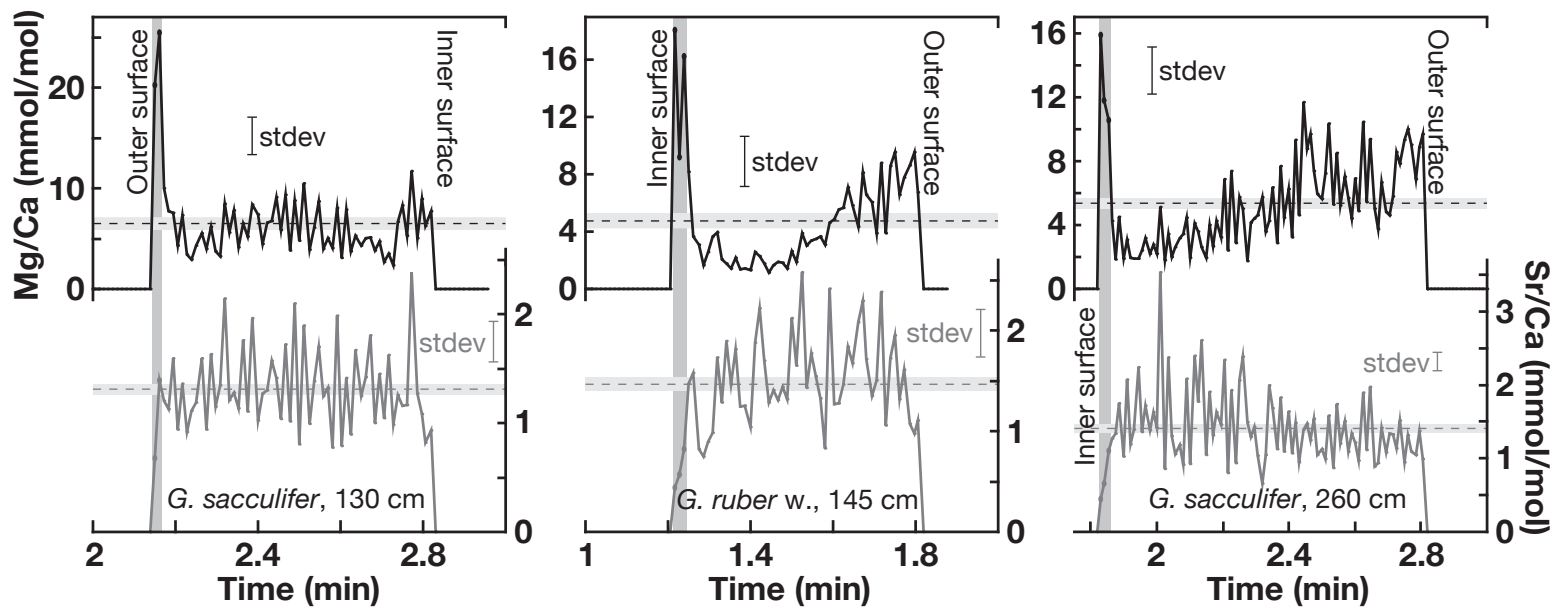

Fig. 10. Time-resolved LA-ICP MS Mg/Ca and Sr/Ca ratios of cleaned foraminiferal samples with diagenetic overgrowths of site SO16419-2: Sample $130 \mathrm{~cm}$ ( $\sim 260 \mathrm{kyrs})$, sample $145 \mathrm{~cm}$ ( $\sim 288 \mathrm{kyrs})$, sample $260 \mathrm{~cm}$ ( $\sim 73 \mathrm{kyrs})$. For detailed description, see Fig. 9.

the test (e.g., Rosenthal and Lohmann, 2002; de Villiers, 2003). Unfortunately, covariation of increased foraminiferal test weights and $\mathrm{Mg} / \mathrm{Ca}$ or $\mathrm{Sr} / \mathrm{Ca}$, respectively, is not straightforward in this study, for instance during MIS 11 and 12 (Fig. 4). Thus, it is improbable to assess reasonable amounts of attached diagenetic calcite by size-normalized test weights. Our approach to estimate the proportion of diagenetic overgrowth necessary to alter the foraminiferal $\mathrm{Mg} / \mathrm{Ca}$ and $\mathrm{Sr} / \mathrm{Ca}$ (Fig. 4) is to apply a mass balance. Endmember phases are an assumed planktonic foraminifera with $\mathrm{Mg} / \mathrm{Ca}$ of $4 \mathrm{mmol} / \mathrm{mol}$ and $\mathrm{Sr} / \mathrm{Ca}$ of $1.4 \mathrm{mmol} / \mathrm{mol}$, characteristic for interglacial $G$. sacculifer, and three possible $\mathrm{Mg} / \mathrm{Ca}(10,20,40 \mathrm{mmol} / \mathrm{mol})$ and two possible $\mathrm{Sr} / \mathrm{Ca}$ signatures $(0.5,0.8 \mathrm{mmol} / \mathrm{mol})$ for the overgrowth, obtained from laser ablation (Table 1). We suggest that a proportion of $10-20 \%$ of crystallites is sufficient to increase (decrease) the $\mathrm{Mg} / \mathrm{Ca}(\mathrm{Sr} / \mathrm{Ca})$ to the extent we observed for sites SO164-074 ( $7 \mathrm{mmol} / \mathrm{mol}$; Fig. 5) and SO164-19-2 back until MIS 13 ( $11 \mathrm{mmol} / \mathrm{mol}$; Fig. 4).

Prior to MIS 13, this straightforward interrelationship between $\mathrm{Mg} / \mathrm{Ca}$ and $\mathrm{Sr} / \mathrm{Ca}$ is no longer visible, although $\mathrm{Mg} / \mathrm{Ca}$ and $\mathrm{Sr} / \mathrm{Ca}$ show similar decreasing trends from MIS 18-20. The recorded $\delta^{18} \mathrm{O}$ trend during this time interval with values around $0.5 \%$ and lack of considerable changes implies that the original planktonic foraminiferal signal has almost completely been overprinted or recrystallized. The early diagenesis of pelagic carbonates has initially been thought to be entirely mechanical compaction down to the ooze-chalk transition zone at approximately 140-200 m sediment depth (e.g., Neugebauer, 1973). Dissolution and reprecipitation of calcite as euhedral calcite crystals inside foraminiferal chambers was observed in samples from below that level (e.g., van der Lingen and Packham, 1975). Model calculations considering pore fluid chemistry, and observations from Antarc- tic shallow water deposits revealed that early diagenesis may commence at much shallower depth in the sediment (Schrag et al., 1995), and that planktonic foraminifers are far more sensitive than other sedimentary components to chemical alteration (Barrera et al., 1987). Recent evidence from sediment cores from the Greenland Sea revealed that this process may occur even at $460 \mathrm{~cm}$ below the seabed, and that the calcite overgrowth substantially biased the original environmental signal recorded in foraminiferal tests (Millo et al., 2005). Their results credence credibility to our observations. It might be speculated that the system for pore fluid changes the way that dissolution and reprecipitation of carbonate takes place, which results in increased $\mathrm{Sr}^{2+}$ and $\mathrm{Mg}^{2+}$ concentrations of coexisting pore fluids (Schrag et al., 1995). A diffusive flux of ions out of the top of the sediment column (Schrag et al., 1995) might have depleted the pore fluid (and elevated the overlying fluids). Such carbonate recrystallization is suggested to have relatively minor effects on $\delta^{18} \mathrm{O}$ values of pore fluid (Schrag et al., 1992).

\subsection{Control of high-magnesium calcite on $\mathrm{Mg} / \mathrm{Ca}$ ratios?}

Aragonite and high-magnesium calcite (HMC) get important in areas around carbonate platforms, which distribute these shallow-water carbonates even down to the deep sea (Morse, 2003). Relatively high proportions of aragonite and HMC (Fig. 3) seem to confirm a recent influence of carbonate production on platforms (i.e. most likely the Bahama platform) on the deep-sea region of the presented sites. Nevertheless, reported aragonite production on the Bahama platform and export towards the deeper basins around the platform during sea-level highstands (Kroon et al., 2000; Rendle et al., 2000; Slowey et al., 2002), possibly mirrored in the aragonite contents of site SO164-07-4, are certainly not reflected 

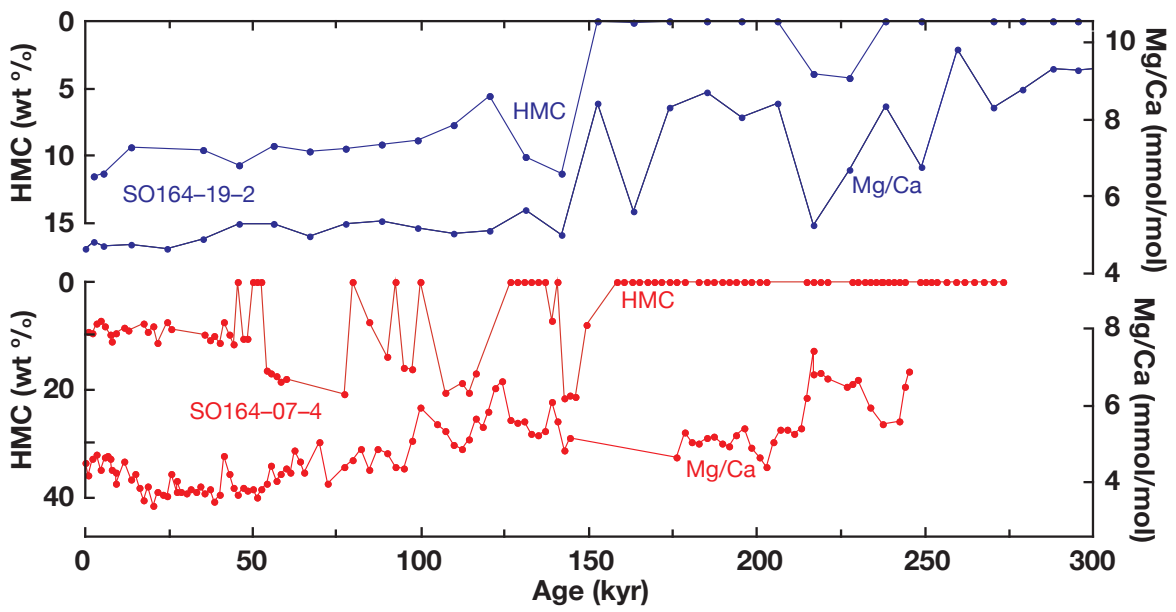

Fig. 11. G. sacculifer $\mathrm{Mg} / \mathrm{Ca}$ ratios and high-magnesium calcite proportion on the carbonate phases of sites SO164-07-4 and SO164-19-2 for the last 300 kyrs: Note that HMC weight percentages are inversely plotted.

in the downcore trend of the carbonate phases of shallow site SO164-19-2. Moreover, absence of aragonite and HMC in sediments of site SO164-19-2 prior to $\sim 300$ kyrs may result from selective dissolution of both phases, which was observed for deeper water $(>1000 \mathrm{~m})$ Bahamian periplatform slope sediments (Mullins et al., 1985; Haak and Schlager, 1989). Associated reprecipitation of low-magnesium calcite in the respective sediments (Mullins et al., 1985) in combination with possible supply of $\mathrm{Mg}^{2+}$ through diffusive flux of ions (Schrag et al., 1995) from the deeper sediment column could provide a source to alter the planktonic foraminiferal geochemical composition to the observed extent. Probably, this is why planktonic foraminiferal $\mathrm{Mg} / \mathrm{Ca}$ ratios and $\mathrm{HMC}$ content of sites SO164-07-4 and SO164-19-2 reveal negatively correlated trends (Fig. 11) with occurrence of anomalously high $\mathrm{Mg} / \mathrm{Ca}$ above $\sim 6 \mathrm{mmol} / \mathrm{mol}$, only when $\mathrm{HMC}$ is absent from the sediments.

\section{Conclusions}

Planktonic foraminiferal $\delta^{18} \mathrm{O}, \mathrm{Mg} / \mathrm{Ca}$, and $\mathrm{Sr} / \mathrm{Ca}$ records of two deep-sea sediment cores (SO164-07-4, 2722 m; SO16419-2, $1704 \mathrm{~m}$ ) from tropical Windward Passage of the last glacial/interglacial cycles reveal values atypical for pelagic environmental conditions. Contemporaneously, $\delta^{18} \mathrm{O}$ and $\mathrm{Mg} / \mathrm{Ca}$ are higher than expected, $\mathrm{Sr} / \mathrm{Ca}$ shows lower ratios than expected. Contamination by $\mathrm{Mg}^{2+}$-bearing $\mathrm{Mn}$-oxide coatings and clay could be ruled out by considerably low foraminiferal $\mathrm{Mn} / \mathrm{Ca}$ and $\mathrm{Fe} / \mathrm{Ca}$.

Scanning electron microscope images display distinct micro-scale veuhydral crystallites of inorganic precipitates on tests with the atypical geochemical composition. Laser ablation measurements of foraminiferal chamber walls identified significantly different $\mathrm{Mg} / \mathrm{Ca}$ (4-6 times elevated) and
Sr/Ca signatures (2-3 times depleted) for the inorganic precipitates in comparison with the actual foraminiferal test.

Back until Marine Isotope Stage 13, crystalline overgrowth proportions of 10-20\%, which cannot by removed by the cleaning procedure applied for foraminiferal $\mathrm{Mg} / \mathrm{Ca}$ analysis, are sufficient to alter the $\mathrm{Mg} / \mathrm{Ca}$ and $\mathrm{Sr} / \mathrm{Ca}$ of the foraminiferal sample calcite to the observed extent. The absence of aragonite and high-magnesium calcite in the sediments prior to $\sim 300 \mathrm{kyrs}$ is likely coupled to selective dissolution within the sediments. It might be speculated that the combined processes of dissolution of these two phases and reprecipitation of low-magnesium calcite contributes as a source for diagenetic alteration of the planktonic foraminiferal geochemical composition. Considering changed interrelationships between the planktonic foraminiferal geochemical parameters prior to marine isotope stage 13, we suggest a diffusive flux of ions out of the top of the sediment column (Schrag et al., 1995) to supply the pore fluid of the overlying sediments. In these sediments, however, planktonic foraminiferal $\mathrm{Mg} / \mathrm{Ca}$ and highmagnesium calcite presence in the respective sediments show the exclusion of anomalously high $\mathrm{Mg} / \mathrm{Ca}(>6 \mathrm{mmol} / \mathrm{mol})$, when HMC is present.

As diagenetic alteration, especially in such shallow-burial sediments, is controlled by very local conditions and processes, similarities of the planktonic foraminiferal $\delta^{18} \mathrm{O}$ and $\mathrm{Mg} / \mathrm{Ca}$ records SO164-07-4, and M35027 as well as M35053 are remarkable (Fig. 5). The vicinity of these sites to carbonate platforms implies similar processes in sediments with dissolution of significant proportions of aragonite and, most important, high-magnesium calcite, and reprecipitation of lowmagnesium calcite. Since $\mathrm{Sr} / \mathrm{Ca}$ seems to most suitably indicate diagenetic alteration by calcite precipitates due to little "natural" variability, Bralower et al. (1997) interpreted 
those $\mathrm{Sr} / \mathrm{Ca}$ of Cretaceous foraminifera as unaltered by diagenetic calcite, which are $>0.9 \mathrm{mmol} / \mathrm{mol}$. In accordance with downcore $\mathrm{Sr} / \mathrm{Ca}$ records (e.g., Martin et al., 1999; Elderfield et al., 2000), we propose the lower level for $\mathrm{Sr} / \mathrm{Ca}$ to exclude alteration by diagenetic calcite for at least MidPleistocene to Holocene of planktonic foraminifera to be as high as $1.2 \mathrm{mmol} / \mathrm{mol}$. However, caution has to be exercised on apparent interspecific variation, which may elevate this lower level.

Acknowledgements. We thank J. J. G. Reijmer, J. Groeneveld, S. Noe, L. Reuning, and S. Steph for insightful discussions. Thoughtful reviews of J. Bijma and D. Lea helped to improve this manuscript. SEM images were prepared at the Institute for Geosciences, Kiel, with the aid of U. Schuldt and L. Lembke-Jene. We also thank B. Bader, D. Garbe-Schönberg, L. Haxhiaj, J. Heinze, K. Kißling, S. Koch, and D. Oesterwind for laboratory know-how and technical support. P. Mason and G. Nubbe are acknowledged for help with LA-ICP MS analyses. Financial support for this research was provided by the German Ministry of Education and Research (BMBF, project No. 03G0164).

Edited by: J. Bijma

\section{References}

Anand, P. and Elderfield, H.: Variability of $\mathrm{Mg} / \mathrm{Ca}$ and $\mathrm{Sr} / \mathrm{Ca}$ between and within the planktonic foraminifers Globigerina bulloides and Globorotalia truncatulinoides, Geochem. Geophys. Geosys., 6, Q11D15, doi:10.1029/2004GC000811, 2005.

Anand, P., Elderfield, H., and Conte, M. H.: Calibration of $\mathrm{Mg} / \mathrm{Ca}$ thermometry in planktonic foraminifera from sediment trap time series, Paleoceanography, 18, 1050, doi:10.1029/2002PA000846, 2003.

Baker, P. A., Gieskes, J. M., and Elderfield, H.: Diagenesis of carbonates in deep-sea sediments: Evidence from $\mathrm{Ca} / \mathrm{Sr}$ ratios and interstitial dissolved $\mathrm{Sr}^{2+}$ data, J. Sediment. Petrol., 52, 71-82, 1982.

Barker, S. and Elderfield, H.: Foraminiferal Calcification Response to Glacial-Interglacial Changes in Atmospheric $\mathrm{CO}_{2}$, Science, 297, 833-836, doi:10.1126/science.1072815, 2002.

Barker, S., Greaves, M., and Elderfield, H.: A study of cleaning procedures used for foraminiferal $\mathrm{Mg} / \mathrm{Ca} \mathrm{pa}-$ leothermometry, Geochem. Geophys. Geosys., 4, 8407, doi:10.1029/2003GC000559, 2003.

Barrera, E., Huber, B. T., Savin, S. M., and Webb, P.-N.: Antarctic marine temperatures: Late Campanian through Early Paleocene, Paleoceanography, 2, 21-47, 1987.

Bassinot, F. C., Labeyrie, L. D., Vincent, E., Quidelleur, X., Shackleton, N. J., and Lancelot, Y.: The astronomical theory of climate and the age of the Brunhes-Matuyama magnetic reversal, Earth Planet. Sci. Lett., 126, 91-108, 1994.

Bé, A. W. H. and Hamlin, W. H.: Ecology of recent planktonic foraminifera, Part 3 - Distribution in the North Atlantic during the summer of 1962, 13, 87-106, doi:10.2307/1484808, 1967.

Bé, A. W. H., Spero, H. J., and Anderson, O. R.: Effects of symbiont elimination and reinfection on the life processes of the planktonic foraminifer Globigerinoides sacculifer, Mar. Biol., 70, 73-86, doi:10.1007/BF00397298, 1982.

Bijma, J., Faber Jr., W. W., and Hemleben, C.: Temperature and salinity limits for growth and survival of some planktonic foraminifers in laboratory cultures, J. Foram. Res., 20, 95-116, 1990.

Boyle, E. A.: Manganese carbonate overgrowths on foraminifera tests, Geochim. Cosmochim. Acta, 47, 1815-1819, 1983.

Brady, H. B.: Supplementary note on the foraminifera of the Chalk (?) of the New Britain Group, Geol. Mag. London, 4, 534-546, 1877.

Bralower, T. J., Fullagar, P. D., Paull, C. K., Dwyer, G. S., and Leckie, R. M.: Mid-Cretaceous strontium-isotope stratigraphy of deep-sea sections, GSA Bull., 109, 1421-1442, 1997.

Broecker, W. S. and Clark, E.: An evaluation of Lohmann's foraminifera weight dissolution index, Paleoceanography, 16, 431-434, doi:10.1029/2000PA000600, 2001.

Brown, S. J. and Elderfield, H.: Variations in $\mathrm{Mg} / \mathrm{Ca}$ and $\mathrm{Sr} / \mathrm{Ca}$ ratios of planktonic foraminifera caused by postdepositional dissolution: Evidence of shallow Mg-dependent dissolution, Paleoceanography, 11, 543-551, 1996.

Carpenter, S. J. and Lohmann, K. C.: Sr/Mg ratios of modern calcite: Empirical indicators of ocean chemistry and precipitation rate, Geochim. Cosmochim. Acta, 56, 1837-1849, 1992.

Crowley, T. J. and Zachos, J. C.: Comparison of zonal temperature profiles for past warm periods, in: Warm Climates in Earth History, edited by: Huber, B. T., MacLeod, K. G., and Wing, S. L., Cambridge University Press, Cambridge, doi:10.2277/052164142X, 50-76, 2000.

Curry, W. B. and Oppo, D. W.: Synchronous, high-frequency oscillations in tropical sea surface temperatures and North Atlantic Deep Water production during the last glacial cycle, Paleoceanography, 12, 1-14, 1997.

de Villiers, S.: A $425 \mathrm{kyr}$ record of foraminiferal shell weight variability in the western equatorial Pacific, Paleoceanography, 18, 1080, doi:10.1029/2002PA000801, 2003.

Dekens, P. S., Lea, D. W., Pak, D. K., and Spero, H. J.: Core top calibration of $\mathrm{Mg} / \mathrm{Ca}$ in tropical foraminifera: Refining paleotemperature estimation, Geochem. Geophys. Geosys., 3, 1022, doi:10.1029/2001GC000200, 2002.

Delaney, M. L., Bé, A. W. H., and Boyle, E. A.: Li, Sr, Mg, and $\mathrm{Na}$ in foraminiferal calcite shells from laboratory culture, sediment traps, and sediment cores, Geochim. Cosmochim. Acta, 49, 1327-1341, doi:10.1016/0016-7037(85)90284-4, 1985.

Droxler, A. W.: Late quaternary glacial cycles in the Bahamian deep basins and in the adjacent Atlantic Ocean, Ph.D. thesis, Miami Univ., Coral Gables, USA, 1984.

Eggins, S., DeDeckker, P., and Marshall, J.: Mg/Ca variation in planktonic foraminifera tests: implications for reconstructing palaeo-seawater temperature and habitat migration, Earth Planet. Sci. Lett., 212, 291-306, 2003.

Elderfield, H., Cooper, M., and Ganssen, G.: Sr/Ca in multiple species of planktonic foraminifera: Implications for the reconstructions of seawater $\mathrm{Sr} / \mathrm{Ca}$, Geochem. Geophys. Geosys., 1, doi:10.1029/1999GC000031, 2000.

Ericson, D. B. and Wollin, G.: Micropaleontological and isotopic determinations of Pleistocene climates, Micropaleontology, 2, 257-270, 1956.

Ericson, D. B. and Wollin, G.: Pleistocene climates and chronology 
in deep-sea sediments, Science, 162, 1227-1234, 1968.

Frank, T. D. and Bernet, K.: Isotopic signature of burial diagenesis and primary lithological contrasts in periplatform carbonates (Miocene, Great Bahama Bank), Sedimentology, 47, 1119-1134, 2000.

Funk, J. A., von Dobeneck, T., Wagner, T., and Kasten, S.: Late Quaternary Sedimentation and Early Diagenesis in the Equatorial Atlantic Ocean: Patterns, Trends and Processes Deduced from Rock Magnetic and Geochemical Records, in: The South Atlantic in the Late Quaternary: Reconstruction of Material Budgets and Current Systems, edited by: Wefer, G., Mulitza, S., and Ratmeyer, V., Springer-Verlag, Berlin, Heidelberg, New York, Tokyo, 461-497, 2003.

Graham, D. W., Bender, M. L., Williams, D. F., and Keigwin, L. D.: Strontium-calcium ratios in Cenozoic planktonic foraminifera, Geochim. Cosmochim. Acta, 46, 1281-1292, doi:10.1016/00167037(82)90012-6, 1982.

Günther, D., Frischknecht, R., Heinrich, C. A., and Kahlert, H. J.: Capabilities of a $193 \mathrm{~nm}$ ArF excimer laser for LA-ICP-MS micro analysis of geological materials, J. Anal. At. Spectrom., 12, 939-944, 1997.

Haak, A. B. and Schlager, W.: Compositional variations in calciturbedites due to sea-level fluctuations, late Quaternary, Bahamas, Int. J. Earth Sci., 78, 477-486, doi:10.1007/BF01776186, 1989.

Haddad, G. A. and Droxler, A. W.: Metastable $\mathrm{CaCO}_{3}$ dissolution at intermediate water depths of the Caribbean and western North Atlantic: Implications form intermediate water circulation during the past 200,000 years, Paleoceanography, 11, 701-716, 1996.

Hastings, D. W., Emerson, S. R., Erez, J., and Nelson, B. R.: Foraminiferal magnesium in Globigerinoides sacculifer as a paleotemperature proxy, Paleoceanography, 13, 161-169, 1998.

Hathorne, E. C., Alard, O., James, R. H., and Rogers, N. W.: Determination of intratest variability of trace elements in foraminifera by laser ablation inductively coupled plasmamass spectrometry, Geochem. Geophys. Geosys., 4, 8408, doi:10.1029/2003GC000539, 2003.

Hecht, A. D.: Intraspecific variation in Recent populations of Globigerinoides ruber and Globigerinoides trilobus and their application to paleoenvironmental analysis, J. Paleontol., 48, 12171234, 1974.

Hemleben, C., Spindler, M., and Anderson, O. R. (Eds.): Modern Planktonic Foraminifera, Springer-Verlag, Berlin, Heidelberg, New York, 1989.

Hover, V. C., Walter, L. M., and Peacor, D. R.: Early marine diagenesis of biogenic aragonite and Mg-calcite: new constraints from high-resolution STEM and AEM analyses of modern platform carbonates, Chem. Geol., 175, 2001.

Jansen, H., Zeebe, R. E., and Wolf-Gladrow, D. A.: Modeling the dissolution of settling $\mathrm{CaCO}_{3}$ in the ocean, Glob. Biogeochem. Cycles, 16, 1027, doi:10.1029/2000GB001279, 2002.

Katz, A.: The interaction of magnesium with calcite during crystal growth at $25-90^{\circ} \mathrm{C}$ and one atmosphere, Geochem. Cosmochim. Acta, 37, 1563-1586, 1973.

Keller, G.: Origin and Evolution of the Genus Globigerinoides in the Early Miocene of the Northwestern Pacific, DSDP Site 292, Micropaleontology, 27, 293-304, 1981.

Kennett, J. P. and Srinivasan, M. S. (Eds.): Neogene Planktonic
Foraminifera, A Phylogenetic Atlas, Hutchinson Ross, Stroudsburg, Pennsylvania, 1983.

Killingley, J. S.: Effects of diagenetic recrystallization on ${ }^{18} \mathrm{O} /{ }^{16} \mathrm{O}$ values of deep-sea sediments, Nature, 301, 594-597, 1983.

Kim, S. T. and O'Neil, J. R.: Equilibrium and nonequilibrium oxygen isotope effects in synthetic carbonates, Geochim. Cosmochim. Acta, 61, 3461-3475, 1997.

Koutavas, A., Lynch-Stieglitz, J., Marchitto Jr., T. M., and Sachs, J.: El Niño-Like Pattern in Ice Age Tropical Pacific Sea Surface Temperature, Science, 297, 226-230, doi:10.1126/science.1072376, 2002.

Kroon, D., Reijmer, J. J. G., and Rendle, R.: 2. Mid- to LateQuaternary variations in the oxygen isotope signature of Globigerinoides ruber at Site 1006 in the western subtropical Atlantic, in: Proc. ODP, Sci. Results, Vol. 166, edited by: Swart, P. K., Eberli, G. P., Malone, M. J., and Sarg, J. F., College Station, TX (Ocean Drilling Program), 13-22, 2000.

Kunioka, D., Shirai, K., Takahata, N., Sano, Y., Toyofuku, T., and Ujiie, Y.: Microdistribution of $\mathrm{Mg} / \mathrm{Ca}, \mathrm{Sr} / \mathrm{Ca}$, and $\mathrm{Ba} / \mathrm{Ca}$ ratios in Pulleniatina obliquiloculata test by using a NanoSIMS: Implication for the vital effect mechanism, Geochem. Geophys. Geosys., 7, Q12P20, doi:10.1029/2006GC001280, 2006.

Lea, D. W., Mashiotta, T. A., and Spero, H. J.: Controls on the magnesium and strontium uptake in planktonic foraminifera determined by live culturing, Geochim. Cosmochim. Acta, 63, 23692379, 1999.

Lohmann, G.: A model for variation in the chemistry of planktonic foraminifera due to secondary calcification and selective dissolution, Paleoceanography, 10, 445-457, 1995.

Lončaríc, N., Peeters, F. J. C., Kroon, D., and Brummer, G.J. A.: Oxygen isotope ecology of recent planktic foraminifera at the central Walvis Ridge (SE Atlantic), Paleoceanography, 21, PA3009, doi:10.1029/2005PA001207, 2006.

Lorens, R. B., Williams, D. F., and Bender, M. L.: The early nonstructual chemical diagenesis of foraminiferal calcite, J. Sediment. Petrol., 47, 1602-1609, 1977.

Malone, M. J., Slowey, N. C., and Henderson, G. M.: Early diagenesis of shallow-water periplatform carbonate sediments, leeward margin, Great Bahama Bank (Ocean Drilling Program Leg 166), GSA Bull., 113, 881-894, 2001.

Martin, P. A., Lea, D. W., Mashiotta, T. A., Papenfuss, T., and Sarnthein, M.: Variation of foraminiferal $\mathrm{Sr} / \mathrm{Ca}$ over Quaternary glacial-interglacial cycles: Evidence for changes in mean ocean Sr/Ca?, Geochem. Geophys. Geosys., 1, doi:10.1029/1999GC000006, 1999.

Martinson, D. G., Pisias, N. G., Hays, J. D., Imbrie, J., T. C. More, J., and Shackleton, N. J.: Age dating and the orbital theory of the ice ages: Development of a high-resolution 0 to 300,000-year chronostratigraphy, Quat. Res., 27, 1-29, 1987.

Mason, P. R. D. and Mank, A. J. G.: Depth-resolved analysis in multi-layered glass and metal materials using laser ablation inductively coupled plasma mass spectrometry (LA-ICP-MS), J. Anal. At. Spectrom., 16, 1381-1388, 2001.

Millo, C., Sarnthein, M., Erlenkeuser, H., Grootes, P. M., and Anderson, N.: Methan-induced early diagenesis of foraminiferal tests in the southwestern Greenland Sea, Mar. Micropal., 58, 112, doi:10.1016/j.marmicro.2005.07.003, 2005.

Morse, J. W.: Formation and Diagenesis of Carbonate Sediments, in: Treatise on Geochemistry - The Oceans and Marine Geo- 
chemistry, Vol. 7, edited by: Mackenzie, F. T., Elsevier Ltd., Oxford, 67-85, 2003.

Mucci, A.: Influence of temperature on the composition of magnesian calcite overgrowths precipitated from seawater, Geochim. Cosmochim. Acta, 51, 1977-1984, 1987.

Mucci, A. and Morse, J. W.: The incorporation of $\mathrm{Mg}^{2+}$ and $\mathrm{Sr}^{2+}$ into calcite overgrowths: influences of growth rate and solution composition, Geochim. Cosmochim. Acta, 47, 217-233, 1983.

Mulitza, S., Donner, B., Fischer, G., Paul, A., Pätzold, J., Rühlemann, C., and Segl, M.: The South Atlantic Oxygen Isotope Record of Planktic Foraminifera, in: The South Atlantic in the Late Quaternary: Reconstruction of Material Budgets and Current Systems, edited by: Wefer, G., Mulitza, S., and Ratmeyer, V., Springer-Verlag, Berlin, Heidelberg, New York, Tokyo, 121-142, 2004.

Müller, A. (Ed.): $\mathrm{Mg} / \mathrm{Ca}-$ und $\mathrm{Sr} / \mathrm{Ca}-$ Verhältnisse in biogenem Carbonat planktischer Foraminiferen und benthischer Ostracoden, Vol. 313, Berichte aus dem Institut für Meereskunde, University of Kiel, Germany, 1999.

Mullins, H. T., Wise Jr., S. W., Gardulski, A. F., Hinchey, E. J., Masters, P. M., and Siegel, D. I.: Shallow subsurface diagenesis of Pleistocene periplatform ooze: northern Bahamas, Sedimentology, 32, 473-494, doi:10.1111/j.1365-3091.1985.tb00465.x, 1985.

Neugebauer, J.: The diagenetic problem of chalk: the role of pressure solution and pore fluid, N. Jb. Geol. Paläont. Abh., 143, 223-245, 1973.

Norris, R. D. and Wilson, P. A.: Low-latitude sea-surface temperatures for the mid-Cretaceous and the evolution of planktic foraminifera, Geology, 26, 823-826, 1998.

Nürnberg, D., Schönfeld, J., Dullo, W.-C., and Rühlemann, C. (Eds.): RV SONNE: Cruise report SO164 RASTA (2002), 109, GEOMAR Report, Kiel, 2003.

O’Neil, J. R., Clayton, R. N., and Mayeda, T. K.: Oxygen isotope fractionation in divalent metal carbonates, J. Chem. Phys., 51, 5547-5558, 1969.

Paillard, D., Labeyrie, L., and Yiou, P.: Macintosh program performs time-series analysis, Eos Trans. AGU, 77, 379, Electronic supplement available at: http://www.agu.org/eos_elec/96097e. html, 1996.

Pearce, N. J. G., Perkins, W. T., Westgate, J. A., Gorton, M. P., Jackson, S. E., Neal, C. R., and Chenery, S. P.: A compilation of new and published major and trace element data for NIST SRM 610 and NIST SRM 612 glass reference materials, Geostandards Newslett., 21, 115-144, 1997.

Pearson, P. N., Shackleton, N. J., Weedon, G. P., and Hall, M. A.: 29. Multispecies planktonic foraminifer stable isotope stratigraphy through Oligocene/Miocene boundary climatic cycles, Site 926, in: Proc. ODP, Sci. Results, Vol. 154, edited by: Shackleton, N. J., Curry, W. B., Richter, C., and Bralower, T. J., College Station, TX (Ocean Drilling Program), 441-449, 1997.

Pearson, P. N., Ditchfield, P. W., Singano, J., Harcourt-Brown, K. G., Nicholas, C. J., Olsson, R. K., Shackleton, N. J., and Hall, M. A.: Warm tropical sea surface temperatures in the Late Cretaceous and Eocene epochs, Nature, 413, 481-487, 2001.

Pena, L. D., Calvo, E., Cacho, I., Eggins, S., and Pelejero, C.: Identification and removal of Mn-Mg-rich contaminant phases on foraminiferal tests: Implications for $\mathrm{Mg} / \mathrm{Ca}$ past temperature reconstructions, Geochem. Geophys. Geosys., 6, Q09P02,
doi:10.1029/2005GC000930, 2005.

Petschick, R. (Ed.): MacDiff - The user-friendly X-ray powder diffractometry analysis tool for Macintosh computers., available at: http://servermac.geologie.uni-frankfurt.de/Staff/Homepages/ Petschick/RainerE.html, 2001.

Price, G. D., Sellwood, B. W., Corfield, R. M., Clarke, L., and Cartlidge, J. E.: Isotopic evidence for palaeotemperatures and depth stratification of Middle Cretaceous planktonic foraminifera from the Pacific Ocean, Geol. Mag., 135, 183-191, 1998.

Regenberg, M., Nürnberg, D., Steph, S., Groeneveld, J., GarbeSchönberg, D., Tiedemann, R., and Dullo, W.-C.: Assessing the dissolution effect on planktonic foraminiferal $\mathrm{Mg} / \mathrm{Ca}$ ratios: $\mathrm{Ev}-$ idence from Caribbean core-tops, Geochem. Geophys. Geosys., 7, doi:10.1029/2005GC001019, 2006a.

Reichart, G.-J., Jorissen, F., Anschutz, P., and Mason, P. R. D.: Single foraminiferal test chemistry records the marine environment, Geology, 31, 355-358, doi:10.1130/0091-7613(2003)031, 2003.

Rendle, R. H., Reijmer, J. J. G., Kroon, D., and Henderson, G. M.: 6. Mineralogy and sedimentology of the Pleistocene to Holocene on the leeward margin of the Great Bahama Bank, in: Proc. ODP, Sci. Results, Vol. 166, edited by: Swart, P. K., Eberli, G. P., Malone, M. J., and Sarg, J. F., College Station, TX (Ocean Drilling Program), 61-76, 2000.

Reuss, A. E.: Neue Foraminiferen aus den Schichten des Österreichischen Tertiärbeckens, Königl. Akad. Wissenschaften Wien, math.-naturviss. Klasse, Denkschriften, 1, 365-390, 1850.

Richter, F. M. and DePaolo, D. J.: Numerical models for diagenesis and the Neogene $\mathrm{Sr}$ isotopic evolution of seawater from DSDP Site 590B, Earth Planet. Lett., 83, 27-38, 1987.

Rosenthal, Y. and Lohmann, G. P.: Accurate estimation of sea surface temperatures using dissolution-corrected calibrations for $\mathrm{Mg} / \mathrm{Ca}$ paleothermometry, Paleoceanography, 17, 1044, doi:10.1029/2001PA000749, 2002.

Rosenthal, Y., Boyle, E. A., and Slowey, N.: Temperature control on the incorporation of magnesium, strontium, fluorine, and cadmium into benthic foraminiferal shells from Little Bahama Bank: Prospects for thermocline paleoceanography, Geochim. Cosmochim. Acta, 61, 3633-3643, 1997.

Ruddiman, W. F.: Pleistocene sedimentation in the equatorial Atlantic: Stratigraphy and faunal paleoclimatology, Geol. Soc. Am. Bull., 82, 283-302, 1971.

Rudnicki, M. D., Wilson, P. A., and Anderson, W. T.: Numerical models of diagenesis, sediment properties, and pore fluid chemistry on a paleoceanographic transect: Blake Nose, Ocean Drilling Program Leg 171B, Paleoceanography, 16, 563-575, 2001.

Rühlemann, C., Mulitza, S., Müller, P. J., Wefer, G., and Zahn, R.: Warming of the tropical Atlantic Ocean and slowdown of thermohaline circulation during the last deglaciation, Nature, 402, 511-514, 1999.

Russell, A. D., Hönisch, B., Spero, H. J., and Lea, D. W.: Effects of seawater carbonate ion concentration and temperature on shell $\mathrm{U}$, $\mathrm{Mg}$, and $\mathrm{Sr}$ in cultured planktonic foraminifera, Geochim. Cosmochim. Acta, 68, 4347-4361, doi:10.1016/j.gca.2004.03.013, 2004.

Sabine, C. L. and Mackenzie, F. T.: Bank-Derived Carbonate Sediment Transport and Dissolution in the Hawaiian Archipelago, Aquatic Geochem., 1, 189-230, 1995.

Schlitzer, R. (Ed.): Ocean Data View, available at: http://www. 
awi-bremerhaven.de/GEO/ODV, 2002.

Schmidt, M. W., Spero, H. J., and Lea, D. W.: Links between salinity variation in the Caribbean and North Atlantic thermohaline circulation, Nature, 428, 160-163, 2004.

Schmidt, M. W., Vautravers, M. J., and Spero, H. J.: Western Caribbean sea surface temperatures during the late Quaternary, Geochem. Geophys. Geosys., 7, Q02P10, doi:10.1029/2005GC000957, 2006.

Schrag, D. P.: Effects of diagenesis on the isotopic record of late Paleogene tropical sea surface temperatures, Chem. Geol., 161, 215-244, 1999.

Schrag, D. P., DePaolo, D. J., and Richter, F. M.: Oxygen isotope exchange in a two-layer model of oceanic crust, Earth Planet. Sci. Lett., 111, 305-317, 1992.

Schrag, D. P., DePaolo, D. J., and Richter, F. M.: Reconstructing past sea surface temperatures: Correcting for diagenesis of bulk marine carbonate, Geochim. Cosmochim. Acta, 59, 2265-2278, doi:10.1016/0016-7037(95)00105-9, 1995.

Sexton, P. F., Wilson, P. A., and Pearson, P. N.: Microstructual and geochemical perspectives on planktic foraminiferal preservation: "Glassy" versus "Frosty", Geochem. Geophys. Geosys., 7, Q12P19, doi:10.1029/2006GC001291, 2006.

Shackleton, N. J., Berger, A., and Peltier, W. R.: An alternative astronomical calibration of the lower Pleistocene timescale based on ODP Site 677, Trans. R. Soc. Edinburgh Earth Sci., 81, 251$261,1990$.

Sime, N. G., de la Rocha, C. L., and Galy, A.: Negligible temperature dependence of calcium isotope fractionation in 12 species of planktonic foraminifera, Earth Planet. Sci. Lett., 232, 51-66, doi:10.1016/j.epsl.2005.01.011, 2005.
Slowey, N. C., Wilber, R. J., Haddad, G. A., and Henderson, G. M.: Glacial-to-Holocene sedimentation on the western slope of Great Bahama Bank, Mar. Geol., 185, 165-176, 2002.

Stoll, H. M. and Schrag, D. P.: Effects of Quaternary sea level cycles on strontium in seawater, Geochim. Cosmochim. Acta, 62, 1107-1118, 1998.

Tripati, A. K., Delaney, M. L., Zachos, J. C., and Anderson, L. D.: Tropical sea-surface temperature reconstruction for the early $\mathrm{Pa}-$ leogene using $\mathrm{Mg} / \mathrm{Ca}$ ratios of planktonic foraminifera, Paleoceanography, 18, 1101, doi:10.1029/2003PA000937, 2003.

van der Lingen, G. J. and Packham, G. H.: Relationships between diagenesis and physical properties of biogenic sediments of the Ontong-Java Plateau (Sites 288 and 289, Deep Sea Drilling Project), in: Init. Rep. DSDP, Vol. 30, edited by: Andrews, J. E. and Gradstein, F. M., U. S. Govt. Printing Office, Washington, 443-481, doi:10.2973/dsdp.proc.30.112.1975, 1975.

Wade, B. S. and Kroon, D.: Middle Eocene regional climate instability: Evidence from the western North Atlantic, Geology, 30, 1011-1014, 2002.

Wang, L.: Isotopic signals in two morphotypes of Globigerinoides ruber (white) from the South China Sea: implications for monsoon climate change during the last glacial cycle, Palaeogeogr., Palaeoclimatol., Palaeoecol., 161, 381-394, doi:10.1016/S00310182(00)00094-8, 2000.

Wolff, T., Mulitza, S., Arz, H. W., Pätzold, J., and Wefer, G.: Oxygen isotope versus CLIMAP (18 ka) temperatures: A comparison from the tropical Atlantic, Geology, 26, 675-678, 1998. 